\title{
Integrating microbial physiology and physio-chemical principles in soils with the MIcrobial-MIneral Carbon Stabilization (MIMICS) model
}

\author{
W. R. Wieder ${ }^{1}$, A. S. Grandy ${ }^{2}$, C. M. Kallenbach ${ }^{2}$, and G. B. Bonan ${ }^{1}$ \\ ${ }^{1}$ National Center for Atmospheric Research, Boulder, Colorado 80307, USA \\ ${ }^{2}$ Department of Natural Resources and the Environment, University of New Hampshire, Durham, NH, USA
}

Correspondence to: W. R. Wieder (wwieder@ucar.edu)

Received: 19 December 2013 - Published in Biogeosciences Discuss.: 17 January 2014

Revised: 12 June 2014 - Accepted: 12 June 2014 - Published: 24 July 2014

\begin{abstract}
A growing body of literature documents the pressing need to develop soil biogeochemistry models that more accurately reflect contemporary understanding of soil processes and better capture soil carbon (C) responses to environmental perturbations. Models that explicitly represent microbial activity offer inroads to improve representations of soil biogeochemical processes, but have yet to consider relationships between litter quality, functional differences in microbial physiology, and the physical protection of microbial byproducts in forming stable soil organic matter (SOM). To address these limitations, we introduce the MIcrobialMIneral Carbon Stabilization (MIMICS) model, and evaluate it by comparing site-level soil $\mathrm{C}$ projections with observations from a long-term litter decomposition study and soil warming experiment. In MIMICS, the turnover of litter and SOM pools is governed by temperature-sensitive MichaelisMenten kinetics and the activity of two physiologically distinct microbial functional types. The production of microbial residues through microbial turnover provides inputs to SOM pools that are considered physically or chemically protected. Soil clay content determines the physical protection of SOM in different soil environments. MIMICS adequately simulates the mean rate of leaf litter decomposition observed at temperate and boreal forest sites, and captures observed effects of litter quality on decomposition rates. Moreover, MIMICS better captures the response of SOM pools to experimental warming, with rapid SOM losses but declining temperature sensitivity to long-term warming, compared with a more conventional model structure. MIMICS incorporates current microbial theory to explore the mechanisms by which
\end{abstract}

litter $\mathrm{C}$ is converted to stable SOM, and to improve predictions of soil $\mathrm{C}$ responses to environmental change.

\section{Introduction}

The response of the terrestrial carbon (C) cycle to projected environmental change remains highly uncertain in Earth system models (Arora et al., 2013; Friedlingstein et al., 2006). Some of this uncertainty results from challenges in representing biological processes that drive exchanges of water, energy and $\mathrm{C}$ between the land surface and the atmosphere. Above ground, Earth system models rely on empirical differences in plant physiology and life history strategies to represent the biogeochemical and biogeophysical effects of vegetation dynamics in global simulations (Bonan, 2008; Roy et al., 1993). Although imperfect, these and other data (e.g., Kattge et al., 2011) are improving and refining the autotrophic, or "green", representations of the terrestrial C cycle (Bonan et al., 2012). Comparatively less attention has been given to revising biologically driven representations of the soil heterotrophic, or "brown", C cycle. Accordingly, Earth system models display wide variation in their soil C projections (Todd-Brown et al., 2013). Given the size of global soil C pools (Hugelius et al., 2013; FAO et al., 2012; Jobbágy and Jackson, 2000) and the potential magnitude of soil C-climate feedbacks (Jones et al., 2003, 2005; Jenkinson et al., 1991), greater attention should be directed towards critically evaluating and improving the theoretical and numerical 
representation of soil biogeochemistry models that are used on multiple scales.

A growing body of literature calls for significant revisions to the theoretical basis for modeling soil $\mathrm{C}$ dynamics (Cotrufo et al., 2013; Dungait et al., 2012; Conant et al., 2011; Schmidt et al., 2011). Traditional soil C stabilization concepts do not explicitly simulate microbial activity or soil microbial communities, but instead strongly emphasize the relationship between litter chemical recalcitrance and soil C storage. By contrast, new theoretical and experimental research shows that soil microbes strongly mediate the formation of soil organic matter (SOM) through the production of microbial products that appear to form mineral-stabilized SOM (Wallenstein et al., 2013; Miltner et al., 2012; Wickings et al., 2012; Kleber et al., 2011; Grandy and Neff, 2008; Six et al., 2006). These insights suggest that basic physiological traits such as microbial growth efficiency (MGE) and growth kinetics have direct influences on litter decomposition rates and net microbial biomass production, while the subsequent turnover of microbial biomass strongly influences input rates to SOM. Furthermore, the ultimate fate of SOM also depends upon the mineral stabilization of these microbially derived inputs. However, despite wide recognition that microbial physiology and soil mineral interactions facilitate the formation of stable SOM, this theoretical insight has not been adequately represented in process-based models.

These emerging concepts highlight the need to simulate explicitly the microbial processes responsible for decomposition and stabilization of organic matter (Todd-Brown et al., 2012; Treseder et al., 2012; Allison et al., 2010; Lawrence et al., 2009; Bardgett et al., 2008; Schimel and Weintraub, 2003), even if the magnitude of microbial control over soil C dynamics in mineral soils remains poorly defined (Schimel and Schaeffer, 2012). Microbially explicit approaches in recent models range in complexity from simple fungal to bacterial ratios (Waring et al., 2013), microbial guilds specializing in different litter C substrates (Miki et al., 2010; Moorhead and Sinsabaugh, 2006), and complex community dynamics (Allison, 2012; Wallenstein and Hall, 2012; Loreau, 2001). These models incorporate the complexity of microbial physiology and competitive interactions in litter decomposition dynamics and provide valuable insight into our understanding of "upstream" soil C inputs, but focus less attention on the stabilization of microbial residues in mineral soils. Other recent work demonstrates that simple non-linear microbial models are feasible on the global scale, and results in divergent responses compared with traditional soil biogeochemistry models (Wieder et al., 2013). Again however, this microbial modeling framework does not adequately capture how microbial physiology and activity may facilitate the stabilization of SOM.

Microbial attributes that regulate microbial residue inputs to SOM and their interactions with the soil matrix are effectively absent in traditional soil biogeochemical models, and poorly accounted for in current microbially based models. Thus, our chief motivation is to develop a process-based modeling framework to explore the potential role of microbial physiology and the stabilization of microbial biomass at the soil-mineral interface as key drivers in the formation of SOM (Miltner et al., 2012; Liang et al., 2011; Bol et al., 2009; Grandy et al., 2009). In this model, litter and SOM turnover are governed by microbial biomass pools, which correspond to different microbial functional types. Inherent physiological differences between microbial functional types provide a basis to begin simulating below-ground biological and metabolic diversity and explore how the relative abundance of different microbial functional groups regulates biogeochemical processes (Miki et al., 2010). Microbial growth rates, growth efficiency and turnover are subject to intrinsic physiological constraints (Beardmore et al., 2011; Molenaar et al., 2009; Dethlefsen and Schmidt, 2007), but are also sensitive to external forces such as resource chemistry (Manzoni et al., 2012; Keiblinger et al., 2010; Steinweg et al., 2008; Rousk and Bååth, 2007; Thiet et al., 2006), such that both community composition and the soil environment should determine the optimization of physiological traits and their downstream influence on SOM dynamics.

We use observational and theoretical insights to guide our incorporation of microbial physiological processes into predictions of SOM stabilization. Physiological differences across species have been linked to life-history strategies optimized for different resource environments (Resat et al., 2012; Beardmore et al., 2011; Russell and Cook, 1995). For instance, in resource-rich environments, fast-growing $r$ strategists (copiotrophs) are typically characterized by a lower MGE but higher growth rates, relative to slower-growing K strategists (oligiotrophs; Fierer et al., 2012; Ramirez et al., 2012; Fierer et al., 2007; Klappenbach et al., 2000; Pianka, 1970). This physiology gives copiotrophs a competitive advantage under resource-rich conditions such that they tend to dominate in these environments. On an individual species level, MGE, growth rates, and turnover are expected to increase as resource quality increases. However, selection for a copiotroph-dominated community may drive up communitylevel growth rates and turnover at the expense of a lower MGE. The effect of this tradeoff on total biomass production and microbially derived inputs to physically protected SOM is uncertain, and remains a challenging, often missing, aspect of microbially based soil $\mathrm{C}$ models.

In order to more rigorously evaluate dynamics between microbial physiology, soil environmental conditions and SOM formation, we introduce a new soil biogeochemistry model, MIMICS (MIcrobial-MIneral Carbon Stabilization). MIMICS incorporates the relationships between microbial physiology, substrate chemical quality, and the physical stabilization of SOM (Wang et al., 2013; Goldfarb et al., 2011; Fontaine and Barot, 2005), with the long-term aim of representing these interactions in global simulations using the Community Land Model (Lawrence et al., 2011). Thus, here 


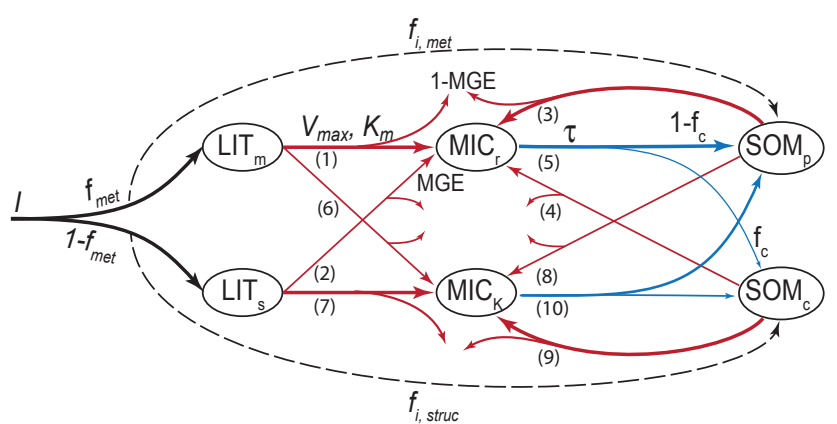

Figure 1. Litter, microbial biomass and soil organic matter (SOM) pools and carbon flows represented in MIMICS. Litter inputs (I; black lines) are partitioned into two litter pools based on litter quality $\left(f_{\text {met }}\right)$. Litter pools in the model correspond to metabolic and structural litter $\left(\mathrm{LIT}_{\mathrm{m}}\right.$ and $\mathrm{LIT}_{\mathrm{s}}$, respectively). Rates of decomposition (red lines) are controlled by temperature-sensitive Michaelis-Menten kinetics derived from observational data (German et al., 2012) that are modified by microbial functional type and C-substrate pool quality. Microbial functional types correspond to copiotrophic and oligiotrophic growth strategies $\left(\mathrm{MIC}_{\mathrm{r}}\right.$ and $\mathrm{MIC}_{\mathrm{K}}$, respectively; Fierer et al., 2007). Microbial growth efficiency (MGE) determines the partitioning of $\mathrm{C}$ fluxes entering microbial biomass pools vs. heterotrophic respiration. Turnover of the microbial biomass pools $(\tau)$ (blue lines) depends on microbial functional type, which are partitioned into physically and chemically protected $\mathrm{SOM}$ pools $\left(\mathrm{SOM}_{\mathrm{p}}\right.$ and $\mathrm{SOM}_{\mathrm{c}}$, respectively, based on $f_{\mathrm{c}}$ ). Decomposition of $\mathrm{C}$ from SOM pools also follows Michaelis-Menten kinetics, with the clay fraction increasing the half-saturation constant for both pools, but especially $\mathrm{SOM}_{\mathrm{p}}$. A fraction of litter inputs $\left(f_{\mathrm{i}}\right)$; dashed black lines) bypasses litter and microbial biomass pools, and is transferred directly to SOM pools.

we explore how microbial physiological traits can be applied to a process-based soil biogeochemistry model; furthermore, we evaluate how incorporating these physiological traits into models may improve our ability to predict soil $\mathrm{C}$ responses to global change scenarios compared with the more traditional DAYCENT model.

\section{Methods}

\subsection{Model configuration}

To develop MIMCS, we modified the CLM microbial model, a soil biogeochemistry model that explicitly represents microbial activity and microbial physiology (Wieder et al., 2013), to simulate two plant litter, microbial biomass, and SOM pools (LIT, MIC and SOM in Fig. 1, respectively). This structure blends aspects of traditional and microbially explicit models. In particular, MIMICS simulates physically and biochemically protected SOM pools that are also represented in the MEND model (Wang et al., 2013), and multiple substrate pools that are represented in the EEZY model (Moorhead et al., 2012), while simplifying the overall model structure by eliminating explicit enzyme pools (Wieder et al., 2013). A vertical dimension could be added to this basic sixpool model structure (Koven et al., 2013), but here we focus on the dynamics simulated within a single soil layer $(0$ $30 \mathrm{~cm}$ ).

The representation of plant litter pools in MIMICS is based on well-established paradigms of litter chemistry and decomposition dynamics (Melillo et al., 1982). We partition fresh litter inputs into high- and low-quality pools LIT $_{m}$ and $\mathrm{LIT}_{\mathrm{s}}$, respectively) that correspond to the metabolic and structural pools used in CENTURY and DAYCENT (Parton et al., 1994; Parton et al., 1987). As in DAYCENT, partitioning into these pools is based on a linear function of litter nitrogen to lignin ratios ( $f_{\text {met }}$; Table 1$)$. A fraction of inputs $\left(f_{\mathrm{i}}\right)$ bypasses litter and microbial biomass pools, and is transferred directly to corresponding SOM pools. For metabolic litter inputs, this fraction is analogous to dissolved organic matter fluxes that leach out of leaf litter or root exudates that quickly become sorbed onto mineral surfaces. For structural litter inputs, this is analogous to a relatively small proportion of the structurally complex compounds that could be incorporated into SOM before microbial oxidation. Thus, $f_{\mathrm{i}}$ for structural litter inputs is inversely related to litter quality (Table 1).

Decomposition of litter and SOM pools is based on temperature-sensitive Michaelis-Menten kinetics (Allison et al., 2010; Schimel and Weintraub, 2003) through the basic equation

$\frac{\mathrm{d} C_{\mathrm{s}}}{\mathrm{d} t}=\mathrm{MIC} \times \frac{V_{\max } \times C_{\mathrm{s}}}{K_{\mathrm{m}}+C_{\mathrm{s}}}$,

where $\mathrm{C}_{s}$ is an individual C substrate pool (LIT or SOM) and MIC corresponds to the size of the microbial biomass pool, both in $\mathrm{mg} \mathrm{C} \mathrm{cm}^{-3}$. Thus, rates of $\mathrm{C}$ mineralization depend on donor C (either LIT or SOM) and receiver (MIC) pool sizes as well as kinetic parameters $V_{\max }$ and $K_{\mathrm{m}}$. The maximum reaction velocity $\left(V_{\max } ; \mathrm{mg} C_{\mathrm{S}}(\mathrm{mg} \mathrm{MIC})^{-1} \mathrm{~h}^{-1}\right)$ and half-saturation constant $\left(K_{\mathrm{m}} ; \mathrm{mg} \mathrm{C} \mathrm{cm}^{-3}\right)$ are respectively calculated as

$V_{\max }=e^{V_{\text {slope }} \cdot T+V_{\text {int }}} \cdot a v \cdot V_{\text {mod }}$

$K_{\mathrm{m}}=e^{K_{\mathrm{slope}} \cdot T+K_{\mathrm{int}}} \cdot a k \cdot K_{\mathrm{mod}}$,

where $T$ represents soil temperature, which we assumed to be $15^{\circ} \mathrm{C}$ unless otherwise noted. The temperature sensitivity of kinetics parameters (described in Table 1) are derived from observational data (German et al., 2012), with modifications based on assumptions regarding microbial functional types, litter chemical quality and soil texture effects $\left(V_{\bmod }\right.$ and $K_{\text {mod }}$; Table 1 ). The equations governing soil $\mathrm{C}$ turnover in MIMICS are provided in the Supplement. Soil moisture is not presently considered in MIMICS, but work by Davidson and others (2012) presents a tractable framework that we can apply to this model structure in the future. 
Table 1. Model parameter descriptions, values, and units used in the MIMICS model.

\begin{tabular}{|c|c|c|c|}
\hline Parameter & Description & Value & Units \\
\hline$f_{\text {met }}$ & Partitioning of litter inputs to $\mathrm{LIT}_{\mathrm{m}}$ & $0.85-0.013\left(\right.$ lignin $\left.\times \mathrm{N}^{-1}\right)$ & - \\
\hline$f_{\mathrm{i}}$ & $\begin{array}{l}\text { Fraction of litter inputs directly transferred } \\
\text { to SOM }\end{array}$ & $0.02,0.3 \times \mathrm{e}^{(-4 \times \text { fmet }) \mathrm{a}}$ & - \\
\hline$V_{\text {slope }}$ & Regression coefficient & $0.063^{b}$ & $\ln \left(\mathrm{mg} \mathrm{C}_{\mathrm{S}}(\mathrm{mg} \mathrm{MIC})^{-1} \mathrm{~h}^{-1}\right)^{\circ} \mathrm{C}^{-1}$ \\
\hline$V_{\text {int }}$ & Regression intercept & $5.47^{\mathrm{b}}$ & $\ln \left(\mathrm{mg} \mathrm{C}_{\mathrm{S}}(\mathrm{mg} \mathrm{MIC})^{-1} \mathrm{~h}^{-1}\right)$ \\
\hline$a_{\mathrm{V}}$ & Tuning coefficient & $8 \times 10^{-6 b}$ & - \\
\hline$V_{\text {mod-r }}$ & $\begin{array}{l}\text { Modifies } V_{\max } \text { for each substrate pool } \\
\text { entering } \mathrm{MIC}_{\mathrm{r}}\end{array}$ & $10,2,6,2^{\mathrm{c}}$ & - \\
\hline$V_{\text {mod-K }}$ & $\begin{array}{l}\text { Modifies } V_{\max } \text { for each substrate pool } \\
\text { entering } \mathrm{MIC}_{\mathrm{K}}\end{array}$ & $2,2,2,2^{\mathrm{d}}$ & - \\
\hline$K_{\text {slope }}$ & Regression coefficient & $0.007^{\mathrm{b}}$ & $\ln \left(\mathrm{mg} \mathrm{C} \mathrm{cm}^{-3}\right){ }^{\circ} \mathrm{C}^{-1}$ \\
\hline$K_{\text {int }}$ & Regression intercept & $3.19^{\mathrm{b}}$ & $\ln \left(\mathrm{mg} \mathrm{C} \mathrm{cm}^{-3}\right)$ \\
\hline$a_{\mathrm{K}}$ & Tuning coefficient & $10^{b}$ & - \\
\hline$K_{\text {mod-r }}$ & $\begin{array}{l}\text { Modifies } K_{\mathrm{m}} \text { for each substrate pool } \\
\text { entering } \mathrm{MIC}_{\mathrm{r}}\end{array}$ & $0.125,0.5, P_{\text {scalar }}, C_{\text {scalar }}{ }^{\mathrm{c}}$ & - \\
\hline$K_{\text {mod-K }}$ & $\begin{array}{l}\text { Modifies } K_{\mathrm{m}} \text { for each substrate pool } \\
\text { entering } \mathrm{MIC}_{\mathrm{K}}\end{array}$ & $0.5,0.25, P_{\text {scalar }}, C_{\text {scalar }}{ }^{\mathrm{d}}$ & - \\
\hline$P_{\text {scalar }}$ & Physical protection scalar used in $K_{\mathrm{mod}}$ & $1 /\left(2.5 \times \mathrm{e}^{(-3 \times \text { fmet })}\right)$ & - \\
\hline$C_{\text {scalar }}$ & Chemical protection scalar using in $K_{\text {mod }}$ & $1 /\left(1.4+0.2\left(f_{\text {clay }}\right)\right)$ & - \\
\hline MGE & $\begin{array}{l}\text { Microbial growth efficiency for } \\
\text { substrate pools }\end{array}$ & $0.6,0.3,0.6,0.3 \mathrm{e}^{\mathrm{e}}$ & $\mathrm{mg} \mathrm{mg}^{-1}$ \\
\hline$\tau$ & Microbial biomass turnover rate & $6 \times 10^{-4} \times \mathrm{e}^{(0.9 \times \text { fmet })}, 3 \times 10^{-4 \mathrm{f}}$ & $\mathrm{h}^{-1}$ \\
\hline$f_{\mathrm{c}}$ & Fraction of $\tau$ partitioned to $\mathrm{SOM}_{\mathrm{c}}$ & $0.2 \times \mathrm{e}^{(-2 \times \text { fmet })}, 0.4 \times \mathrm{f}^{(-3 \times \text { fmet }) \mathrm{f}}$ & - \\
\hline
\end{tabular}

${ }^{a}$ For metabolic litter inputs entering $\mathrm{SOM}_{\mathrm{p}}$ and structural litter inputs entering $\mathrm{SOM}_{\mathrm{c}}$, respectively.

b From observations in German et al. (2012), as used in Wieder et al. (2013).

${ }^{c}$ For $\mathrm{LIT}_{\mathrm{m}}, \mathrm{LIT}_{\mathrm{s}}, \mathrm{SOM}_{\mathrm{p}}$, and $\mathrm{SOM}_{\mathrm{c}}$ fluxes entering $\mathrm{MIC}_{\mathrm{r}}$, respectively.

${ }^{\mathrm{d}}$ For $\mathrm{LIT}_{\mathrm{m}}, \mathrm{LIT}_{\mathrm{s}}, \mathrm{SOM}_{\mathrm{p}}$, and $\mathrm{SOM}_{\mathrm{c}}$ fluxes entering $\mathrm{MIC}_{\mathrm{K}}$, respectively.

${ }^{\mathrm{e}}$ For C leaving $\mathrm{LIT}_{\mathrm{m}}$, LIT $\mathrm{s} \mathrm{SOM}_{\mathrm{p}}$, and $\mathrm{SOM}_{\mathrm{c}}$, respectively.

${ }^{\mathrm{f}}$ For $\mathrm{MIC}_{\mathrm{r}}$ and $\mathrm{MIC}_{\mathrm{K}}$, respectively.

Two microbial functional types are represented in MIMICS that roughly correspond to copiotrophic and oligotrophic growth strategies $\left(\mathrm{MIC}_{\mathrm{r}}\right.$ and $\mathrm{MIC}_{\mathrm{K}}$, respectively; Lipson et al., 2009; Dethlefsen and Schmidt, 2007; Fierer et al., 2007). We have intentionally classified our microbial functional types based on these broad ecological life-history traits because they explicitly parameterize the growth physiologies we are exploring in MIMICS and avoid the exclusivity of fungal : bacterial ratios (Strickland and Rousk, 2010). We assume that the copiotrophic community $\left(\mathrm{MIC}_{\mathrm{r}}\right)$ has a higher growth rate when consuming metabolic litter and physically protected soil $\mathrm{C}$ because of the relatively low $\mathrm{C}: \mathrm{N}$ ratio and the chemical complexity of these pools (LIT $\mathrm{m}$ and $\mathrm{SOM}_{\mathrm{p}}$, respectively), whereas the kinetics of the oligotrophic community $\left(\mathrm{MIC}_{\mathrm{K}}\right)$ are comparatively more favorable when consuming structural litter and chemically protected soil C $\left(\mathrm{LIT}_{\mathrm{S}}\right.$ and $\mathrm{SOM}_{\mathrm{c}}$, respectively; Fig. 1, Table 1) relative to $\mathrm{MIC}_{\mathrm{r}}$. We recognize the uncertainties in these classifications, but argue that they provide a tractable starting point to begin representing microbial metabolic diversity in regional- to global-scale models. We consider the $\mathrm{SOM}_{\mathrm{p}}$ pool to be largely derived of low $\mathrm{C}: \mathrm{N}$ labile materials that are either microbial products or highly processed litter (Grandy and Neff, 2008), whereas the more low-quality $\mathrm{SOM}_{\mathrm{c}}$ pool consists of litter that is higher in structural $\mathrm{C}$ compounds such as lignin.

We implement the physical protection of SOM through environmental scalars that increase the $K_{\mathrm{m}}$ of SOM pools with increasing soil clay content. This environmental scalar is more dramatic for the physically protected SOM pool $\left(\mathrm{SOM}_{\mathrm{p}}\right)$ than it is for the chemically protected pool $\left(\mathrm{SOM}_{\mathrm{c}}\right)$, and strongly reduces microbial access to substrates in mineral soils (Schimel and Schaeffer, 2012). Other aspects of soil mineralogy certainly regulate SOM stabilization (Heckman et al., 2013; Kramer et al., 2012; Kaiser et al., 2011; von Lützow et al., 2008; Jastrow et al., 2007), but in order to represent microbially driven soil biogeochemical processes on global scales, we constrain the complexity of our parameterization to clay content, shown to be a primary factor in physical stabilization mechanisms (Kleber et al., 2011; Mikutta et al., 2006; Sollins et al., 1996).

Microbial growth efficiency determines the fraction of assimilated $\mathrm{C}$ that builds microbial biomass (del Giorgio and Cole, 1998). We have incorporated new experimental insights into the model's MGE dynamics by first accounting 
for substrate quality, which is positively related to MGE (Frey et al., 2013; Keiblinger et al., 2010; Steinweg et al., 2008; Table 1). Second, we explore the theoretical evidence that there is differential MGE for each microbial functional type whereby, for a given substrate, fast-growing copiotrophic communities should have lower growth efficiency than slower growing oligotrophic communities (Sinsabaugh et al., 2013; Lipson et al., 2009; Fierer et al., 2007; Pfeiffer et al., 2001; Russell and Cook, 1995). We recognize the importance of considering MGE sensitivity to changes in temperature and nutrient availability in refining our understanding of microbial physiological responses to perturbations (Lee and Schmidt 2013; Tucker et al., 2013; Wieder et al., 2013; Manzoni et al., 2012; Bradford et al., 2008; Frey et al., 2008; Steinweg et al., 2008), although these theoretical considerations are not addressed in this manuscript.

A fixed fraction of the microbial biomass pools turns over $(\tau)$ at every time step, with partitioning into physically and chemically protected SOM pools dependent on the chemical quality of litter inputs $\left(f_{\mathrm{c}}\right.$; Table 1$)$. We assume that the turnover rates of copiotrophic microbial communities will be greater than their oligotrophic counterparts (Fierer et al., 2007), and that the turnover of $\mathrm{MIC}_{\mathrm{r}}$ will increase with higher quality litter inputs. We also assume that the majority of $\tau$ will be partitioned into the physically protected SOM pool, especially from $\mathrm{MIC}_{\mathrm{r}}$, and that partitioning into chemically protected pools will be inversely related to litter quality.

\subsection{Model evaluation: litter decomposition study}

Validating assumptions and parameterization in MIMICS presents unique challenges. Given the difficulty in obtaining empirical data on MGE and microbial turnover, and the methodological limitations in resolving the flow of microbial C into SOM (Six et al., 2006), our model evaluation is restricted to the litter fluxes and decomposition dynamics that are represented in the left portion of our model (Fig. 1). Leaf litter decomposition studies provide process-level evaluation of soil $\mathrm{C}$ dynamics across biomes and with multiple litter types (Bonan et al., 2013; Yang et al., 2009). We take a similar approach in evaluating MIMICS, using data from the LIDET study. LIDET was a decade-long multisite study designed to investigate climate-litter quality dynamics in decaying litter (Currie et al., 2010; Harmon et al., 2009; Adair et al., 2008; Parton et al., 2007; Gholz et al., 2000). Here we used a subset of LIDET data (from Parton et al., 2007) that has been used previously to evaluate litter decomposition dynamics in Earth system models (Bonan et al., 2013). Although similar exhaustive evaluations of leaf litter decomposition dynamics are outside the scope of this paper, we used data from six leaf litters of varying chemical quality decomposed at two LIDET sites (Harvard Forest and Bonanza Creek) to begin evaluating process-level simulations provided by our non-linear microbial model.
Litterbag studies are relatively simple to replicate using traditional soil biogeochemistry models based on first-order kinetics (Bonan et al., 2013). In these donor control models pool size has no bearing on rates of litter decay, so decomposition dynamics can be simulated by adding a fixed amount of litter to appropriate pools subject to environmental scalars (e.g., soil temperature and soil moisture) that modulate base rates of decomposition over time. However, in MIMICS, decomposition does not follow simple first-order kinetics because the size of both the donor and receiver pools modulates decay rates via environmentally sensitive microbial kinetics parameters (Eq. 1). Since the size of the microbial biomass pools exerts a strong influence over rates of litter decay, MIMICS had to be equilibrated at steady state before adding a cohort of litter to track over the experimental period. Second, augmenting litter pools initially increased rates of decomposition and enlarged microbial biomass pools, which further accelerated decomposition rates (see Eq. 1). To overcome these complications we took several steps to facilitate the evaluation of leaf litter decomposition studies using nonlinear microbial models.

We applied a Newton-Raphson approach to analytically calculate steady-state $\mathrm{C}$ pools using the stode function in the rootSolve package in $\mathrm{R}$ ( $\mathrm{R}$ Development Core Team, 2011; Soetaert, 2009). We calculated steady-state pools and site productivity estimates at the Harvard Forest and Bonanza Creek Long-Term Ecological Research sites (Knapp and Smith, 2001). Mean annual soil temperatures were estimated as 10.7 and $3.9^{\circ} \mathrm{C}$ at Harvard Forest (May 2001-October 2010) and Bonanza Creek (June 1984December 2004), respectively (data from the Climate and Hydrology Database Projects - a partnership between the Long-Term Ecological Research program and the US Forest Service Pacific Northwest Research Station, Corvallis, Oregon; http://climhy.lternet.edu/, accessed August 2013). Productivity estimates provided litter inputs that were distributed at hourly intervals evenly throughout the year. We created a daily climatology from a decade or more of soil temperature records at each site and calculated steady-state pools with hourly litter inputs and mean annual soil temperature. We assumed soils at both sites had $10 \%$ clay content and metabolic litter inputs were $30 \%$ of total litter inputs. From their steady states, models for each site were run for an additional thirty years with hourly litter inputs and daily soil temperature climatologies, allowing all $\mathrm{C}$ pools to equilibrate to seasonally fluctuating temperatures. Data for control simulations continued beyond this equilibration period for an additional decade. In experimental simulations we added $100 \mathrm{~g} \mathrm{C} \mathrm{m}^{-2}$ to litter pools on October first, with partitioning between $\mathrm{LIT}_{\mathrm{m}}$ and $\mathrm{LIT}_{\mathrm{s}}$ dependent on litter quality $\left(f_{\mathrm{met}}\right.$, Table 1). To avoid changing results by augmenting microbial biomass pools through this litter addition (Eq. 1), we forced the experimental simulation to maintain the same microbial biomass pool as the control simulation. We calculated the percent mass remaining as the difference in litter pools from 
experimental and control simulations. Model parameterizations were modified to provide the best fit for the Harvard Forest data, and independently evaluated using the results from Bonanza Creek.

\subsubsection{Model evaluation: Soil warming experiment}

Litter decomposition studies provide validation for processbased representation of models under steady-state conditions, but the Community Earth System Model into which we aim to integrate MIMICS is used to project $\mathrm{C}$ cycle-climate feedbacks in a changing world. It is in these non-steadystate simulations that differences in model structures, assumptions and parameterizations become important (Wieder et al., 2013). Thus, we compare the soil C response of MIMICS and DAYCENT to experimental warming in simulations designed to replicate the experimental warming manipulations at Harvard Forest (Melillo et al., 2011, 2002).

We calculated steady-state soil C pools $(0-30 \mathrm{~cm})$ for DAYCENT and MIMICS models using site-level productivity estimates (Knapp and Smith, 2001), mean annual soil temperature (here from Harmon, 2013), soil texture data (S. Frey, personal communication, 2014), and litter quality estimates for deciduous forests from the TRY database (Brovkin et al., 2012; as in Wieder et al., 2014). For DAYCENT simulations we used a soil $\mathrm{pH}=3.8$ (Melillo et al., 2002) and solved the steady-state $C$ pools as described in Wieder et al. (2014) with modifications to simulate $0-30 \mathrm{~cm}$ soils (Metherell et al., 1993), with a climate decomposition index (CDI) of 0.27. This CDI value was calculated using the temperature scalar formula described by Metherell and others (1993) and allows us to revise CDI values in the warming experiment. Despite omitting effects of soil moisture in our CDI calculations, our initial CDI value is close to CDI estimates for Harvard Forest used previously (0.25; Parton et al., 2007 and Bonan et al., 2013). From our steady-state pools we simulated control and $5{ }^{\circ} \mathrm{C}$ warming experiments for 500 years, focusing on results from the first 20 years. Experimental evidence also shows that MGE decreases with warming, approximately $1 \%{ }^{\circ} \mathrm{C}^{-1}$, although temperature-induced changes in MGE likely depend on the chemical quality of substrates and potential acclimation of the microbial community to extended warming (see Frey et al., 2013). Here we consider the potential effects of changing MGE in warming experiments by repeating our simulation with a $5 \%$ reduction in MGE for all fluxes simulated by MIMICS and DAYCENT, respectively.

We compare changes in SOM pools and total soil C pools simulated by MIMICS and DAYCENT with observed results from two sets of warming experiments from Harvard Forest (Melillo et al., 2011, 2002). We present results from the SOM pools represented by each model, and the total change in soil C storage with warming. Analysis of SOM pools ignores changes in litter and microbial biomass pools (Fig. 1; see also Bonan et al., 2013, for the DAYCENT pool structure). Ob- servational data were extracted from published figures using the DataThief software package (http://datathief.org/). We assumed that $80 \%$ of the soil respiration values reported by Melillo and others (2002) were attributable to heterotrophic respiration. The cumulative soil C losses we calculated with this approach are identical for the Melillo et al. (2011) results (1300 $\mathrm{g} \mathrm{C} \mathrm{m}^{-2}$ over seven years), and slightly greater than those reported in the 2002 study (we calculate cumulative $\mathrm{C}$ losses over the ten-year study of $1071 \mathrm{~g} \mathrm{C} \mathrm{m}^{-2}$ vs. $944 \mathrm{~g} \mathrm{C} \mathrm{m}^{-2}$ reported by Melillo et al., 2002).

\subsection{Steady-state soil $\mathrm{C}$ pools and sensitivity analysis}

Initial parameter values were evaluated with data from LIDET sites to explore how steady-state litter, microbial biomass and soil $\mathrm{C}$ pools vary with soil texture and litter chemical quality. We calculated steady-state conditions for all MIMICS pools using the stode function. Soil texture effects on turnover of SOM pools $\left(\mathrm{P}_{\text {scalar }}\right.$ and $C_{\text {scalar }}$; Table 1) provide a strong influence on steady-state SOM pools. We chose values for these parameters assuming that lowclay soils would provide low physical protection of soil C (i.e, low $K_{\mathrm{m}}$ ), which increases exponentially with increasing soil clay content (Table 1). We furthermore constrained initial parameterizations to keep the ratio of total soil microbial biomass to SOM roughly within observational constraints (Serna-Chavez et al., 2013; Xia et al., 2012). This provides useful bounds because much larger SOM pools can be simulated with this model by adjusting soil texture effects on the half-saturation constant for $\mathrm{C}$ fluxes from SOM to microbial biomass pools (using the $P_{\text {scalar }}$ and $C_{\text {scalar }}$, Table 1). From these initial conditions (Table 1) we modified individual parameters by $10 \%$ to illustrate important model assumptions, characteristics, and uncertainties.

Recent analyses have criticized the unrealistic dynamics produced in the numerical application of microbially explicit models, notably their oscillatory behavior in response to perturbations (Li et al., 2014, Wang et al., 2014). To begin exploring these dynamics in MIMICS, we replicated the part of the numerical simulations employed by Wang and others (2014). We calculated steady-state $C$ pools $(0-30 \mathrm{~cm})$ for a hypothetical site with a mean temperature of $15^{\circ} \mathrm{C}$ that receives litter inputs of $372.3 \mathrm{~g} \mathrm{C} \mathrm{m}^{-2} \mathrm{y}^{-1}$. Using parameter values described in Table 1, we prescribe the fraction of metabolic litter inputs and the soil clay fraction $\left(f_{\text {met }}=0.3\right.$ and $f_{\text {clay }}=0.2$ ). From their steady-state values, we reduced microbial biomass and SOM pools by $10 \%$ at time zero, and ran MIMICS for a fifty-year simulation to track changes in litter, microbial biomass, and soil $\mathrm{C}$ pools. We stress that our aim with this simulation is not to provide a rigorous mathematical analysis of MIMICS, but to illustrate the magnitude of the oscillatory response produced by the parameters applied in the model. 

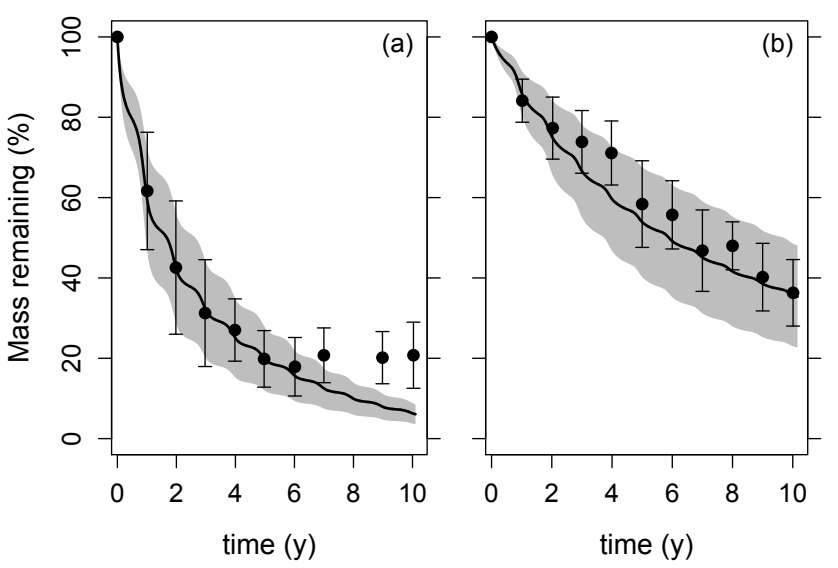

Figure 2. Observed and modeled leaf litter decomposition dynamics at the (a) Harvard Forest and (b) Bonanza Creek Long-Term Ecological Research sites. Closed circles show the mean percent mass remaining of six leaf litter types decomposed over ten years as part of the LIDET study (Parton et al., 2007; Bonan et al., 2013; mean $\pm 1 \mathrm{SD}$ ). Similarly, solid lines indicate the mean percent mass remaining ( $\pm 1 \mathrm{SD}$, shaded region) of the six leaf litter types predicted by the microbial model forced with a climatology of observed mean daily soil temperature at each study site. Model parameters were calibrated to fit observations from Harvard Forest (Table 1). The same parameters were used to evaluate model output at the Bonanza Creek site. In observations and simulations the range of variation shows the effects of litter quality on rates of litter mass loss.

\section{Results}

\subsection{Model evaluation: litter decomposition}

In Fig. 2 we show the mean percentage mass remaining $( \pm 1 \mathrm{SD})$ of six different leaf litter types decomposed at Harvard Forest and Bonanza Creek for LIDET observations (points and error bars) and MIMICS simulations (lines and shaded area). After calibrating model parameters to fit LIDET observations from Harvard Forest (Table 1), MIMICS can replicate litter decomposition dynamics well at both sites. Beyond capturing the mean state that reflects broad climatic influences on leaf litter decomposition, the observed litter quality effects on litter decomposition rates (error bars) are simulated well in the model (shaded area). These results indicate that the parameterization of litter decay dynamics in MIMICS can replicate real-world observations and demonstrate that microbially explicit models of moderate complexity can be parameterized to preform just as well as standard soil biogeochemistry models based on first-order kinetics (e.g., Bonan et al., 2013).

The final litter mass remaining was lower than that observed by LIDET at the warmer Harvard Forest site (Fig. 2a), suggesting that a third litter $\mathrm{C}$ pool corresponding to leaf litter lignin may be necessary to capture the long tail of leaf litter decomposition dynamics (Adair et al., 2008). Some of

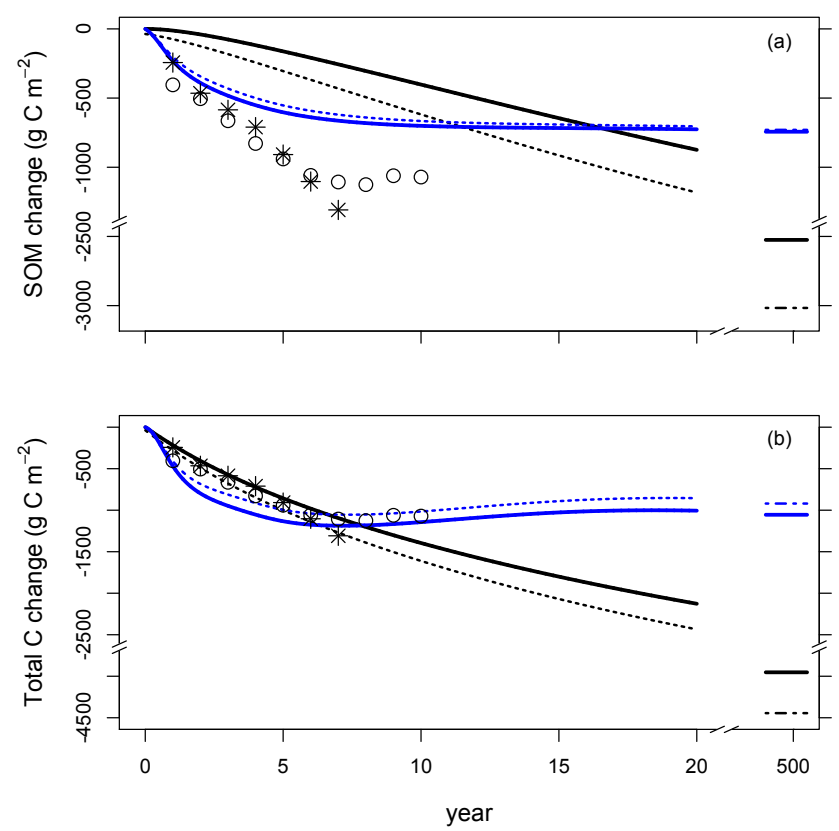

Figure 3. Changes from steady-state (a) SOM pools and (b) total soil C pools at Harvard Forest simulated by DAYCENT (black) and MIMICS (blue). Lines show model results from a $5{ }^{\circ} \mathrm{C}$ warming (solid lines) and warming with $5 \%$ decreases in MGE (dashed lines; sensu Frey et al., 2013). Points are for observations reported by Melillo et al., 2002 (open circles) and Melillo et al., 2011 (stars). Note the breaks on both the $x$ and $y$ axes showing long-term projections from each simulation.

our model assumptions we made to facilitate good agreement with LIDET observations exerted negligible effects on steady-state SOM pools, while other assumptions had a significant influence. For example, our assumption that soils at both sites contained ten percent clay had no bearing on litter decomposition dynamics because, when parameterized, the clay fraction only modifies steady-state SOM pools. By contrast, assumptions about the metabolic fraction of litter inputs exert a significant influence on litter decomposition dynamics by modifying the steady-state size of all simulated pools. Specifically, decreasing the $f_{\text {met }}$ generates comparable total microbial biomass pools, but with a larger proportion of biomass in the oligotrophic $\left(\mathrm{MIC}_{\mathrm{K}}\right)$ community. The oligotrophic community decomposes leaf litter more slowly, resulting in lower rates of mass loss (Wieder, unpublished data). More broadly, any parameter that modifies the steadystate size of microbial biomass pools will strongly influence the temporal dynamics of the model, although such modifications may have little or no effect on steady-state soil C storage.

\subsection{Model evaluation: soil warming experiment}

Initial total soil $\mathrm{C}$ pools simulated for Harvard Forest using MIMICS are significantly smaller than those projected 
by DAYCENT (4.2 and $11.7 \mathrm{~kg} \mathrm{C} \mathrm{m}^{-2}$, respectively; $0-$ $30 \mathrm{~cm}$ ). Observations from these same sites report soil $\mathrm{C}$ pools of $8.4 \mathrm{~kg} \mathrm{Cm}^{-2}(0-60 \mathrm{~cm}$; Melillo et al., 2002) and $6.7 \pm 0.3 \mathrm{~kg} \mathrm{C} \mathrm{m}^{-2}(0-20 \mathrm{~cm}$; Frey et al., 2013). Neither model project changes in SOM pools with warming that are large enough to match observed results (Fig. 3a). Simulated total soil $\mathrm{C}$ losses from each model approach observations over the first decade, but differ greatly on longer timescales (Fig. 3b). Initial soil $\mathrm{C}$ losses $(0-5$ years) simulated by MIMICS may be too rapid, but decreasing effects of soil warming on longer timescales show better agreement with observations from Harvard Forest (Melillo et al., 2002) compared with DAYCENT. By contrast, DAYCENT demonstrates good agreement with data from the observational period, but continues to lose soil $\mathrm{C}$ over the following decades to centuries and has still not reached equilibrium after 500 years (data not shown).

Model responses to reductions in MGE elicited opposing responses in the soil models we examined. In MIMICS, reducing MGE reduces the size of the microbial biomass pool, concurrently decreasing rates of litter and SOM turnover (Eq. 1). These effects are negligible for changes in SOM pools, especially over longer timescales (Fig. 3a), because turnover of microbial residues that contribute to SOM formation are also reduced. Reducing MGE and microbial biomass pools, however, has larger implications for litter $\mathrm{C}$ dynamics in MIMICS (evident in Fig. 3b). Reductions in microbial biomass serve as a counterbalance to the accelerated microbial kinetics associated with warming (see also Wieder et al., 2013, and Allison et al., 2010) and reduce total soil $\mathrm{C}$ losses. Such feedbacks are absent from models like DAYCENT; thus, warming-induced decreases of MGE accelerates $\mathrm{C}$ losses from traditional soil biogeochemistry models.

\subsection{Steady-state soil C pools: influence of litter inputs}

Soil C pools in MIMICS vary as a function of litter quality and soil texture (Fig. 4), with a high metabolic fraction of litter providing the widest range of steady-state values (from 4.8 to $23 \mathrm{mg} \mathrm{C} \mathrm{cm}^{-3}$ in low-clay and high-clay soils, respectively). In soils with low clay content $(<0.3$ clay fraction) receiving low-quality litter inputs $\left(<0.2 f_{\text {met }}\right)$, the chemically protected SOM pool was larger than the physically protected SOM pool; however, in all other cases the majority of SOM was found in the physically protected SOM pool. Reducing litter inputs by $10 \%$ directly reduced the size of microbial biomass pools by $10 \%$, with no changes to the size of steadystate litter or SOM pools.

At steady state the total litter pool size (the sum of LIT $_{m}$ and $\mathrm{LIT}_{\mathrm{S}}$ ) was inversely related to the fraction of metabolic inputs, ranging from 1.7 to $3.2 \mathrm{mg} \mathrm{Cm}^{-3}$ (with high and low $f_{\text {met }}$, respectively). The proportion of total litter found in the metabolic litter pool increased exponentially with increasing $f_{\text {met }}$. Total microbial biomass pool size was relatively invariant with litter quality and soil clay content

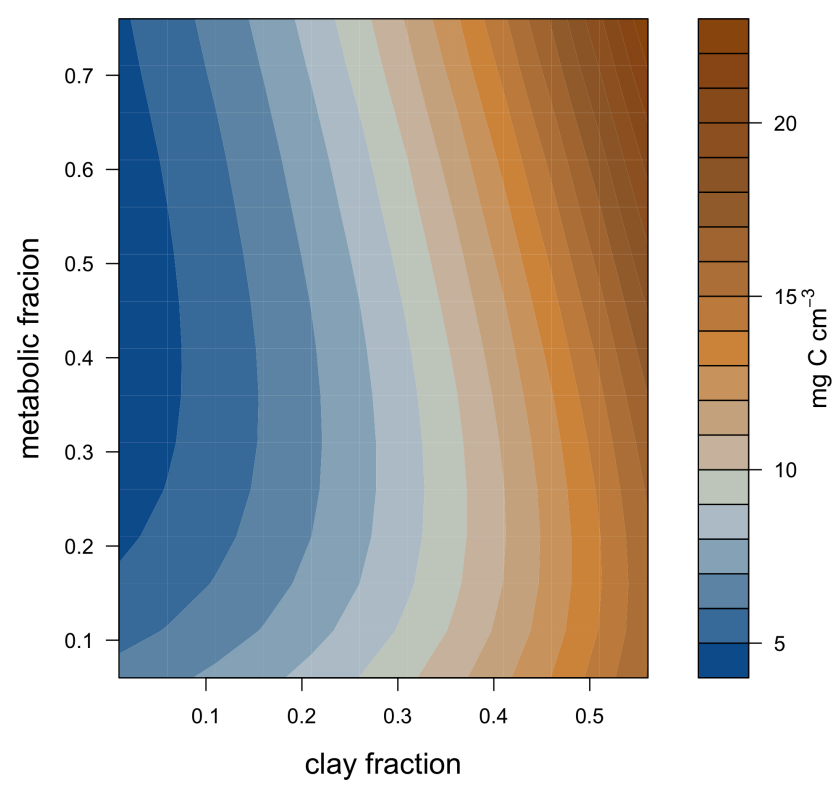

Figure 4. Steady-state soil organic matter pools $\left(\mathrm{mg} \mathrm{Ccm}^{-3}, 0_{-}\right.$ $30 \mathrm{~cm}$ ) that are simulated by MIMICS across hypothetical sites with a range of clay content and litter quality at $15^{\circ} \mathrm{C}$ with litter inputs of $160 \mathrm{~g} \mathrm{C} \mathrm{m}^{-2} \mathrm{y}^{-1}$. Low-clay soils store more $\mathrm{C}$ when receiving low-quality litter inputs, whereas high-clay soils store more $\mathrm{C}$ with high-quality litter inputs.

(0.10-0.11 $\left.\mathrm{mg} \mathrm{C} \mathrm{cm}^{-3}\right)$, totaling about $1-2 \%$ of SOM pools. The relative abundance of $\mathrm{MIC}_{\mathrm{r}}$ increased from approximately $13 \%$ of the total microbial biomass pool with lowquality litter inputs, to nearly $54 \%$ with high-quality litter inputs (Fig. 5a).

\subsection{Steady-state soil C pools: influence of microbial physiology}

We assumed that microbial functional types control the Michaelis-Menten kinetics of litter mineralization. By contrast, the physical soil environment exerts a strong control over the half-saturation constant of SOM mineralization, with modest differences in the $V_{\max }$ driven by microbial functional types (Table 1). Thus, MIMICS illustrates how functional differences between microbial functional types can regulate the fate of $\mathrm{C}$ substrates and affect steady-state SOM pools, either directly or indirectly. We illustrate these dynamics with a series of sensitivity analyses where we perturb individual parameters by $10 \%$ and document their effect on the steady-state soil C pool simulated by MIMICS.

Litter quality determines the relative abundance of microbial functional types in MIMICS. These results, however, depend on the competitive dynamics between microbial functional types that are directly related to assumptions made about the catabolic potential, MGE, and the turnover rates of the $\mathrm{MIC}_{\mathrm{r}}$ and $\mathrm{MIC}_{\mathrm{K}}$ communities (Fig. 5a). For example, reducing the catabolic potential of litter mineralization for 

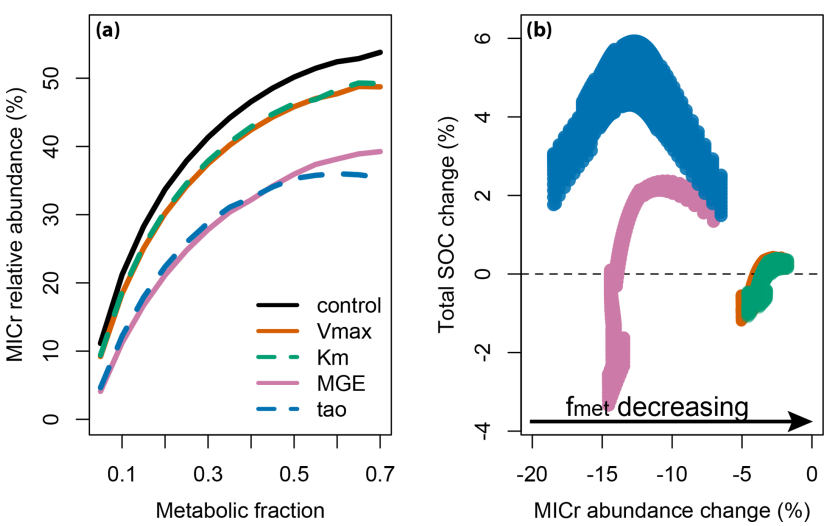

Figure 5. Proximal controls over the production and turnover of microbial biomass (MGE and $\tau$ ) in MIMICS have larger influence over the relative abundance of microbial functional types and steadystate SOM dynamics. (a) The relative abundance of the copiotrophic community $\left(\mathrm{MIC}_{\mathrm{r}} /\right.$ total microbial biomass $\left.\times 100\right)$ as a function of litter quality $\left(f_{\text {met }}\right)$ in base simulations (black line; parameters as in Table 1) and in response to $10 \%$ reductions in catabolic potential of the $\mathrm{MIC}_{\mathrm{r}}$ community consuming litter $\mathrm{C}$ substrates (reducing $V_{\text {max }}$, red line; increasing $K_{\mathrm{m}}$, green line); simulating substrate and community effects on MGE (by reducing MGE of $\mathrm{MIC}_{\mathrm{r}} 10 \%$; blue line); and increasing turnover $(\tau)$ of the $\mathrm{MIC}_{\mathrm{r}}$ community by $10 \%$ (cyan line). (b) Differences between the base simulation and modifications described in panel A on the percent change in steady-state SOM pools vs. the change in the $\mathrm{MIC}_{\mathrm{r}}$ relative abundance.

the copiotrophic community $\mathrm{MIC}_{\mathrm{r}}$, either by reducing $V_{\max }$ or increasing $K_{\mathrm{m}}$, reduces the relative abundance of $\mathrm{MIC}_{\mathrm{r}}$ by $2-5 \%$ across soil textures. This decline in $\mathrm{MIC}_{\mathrm{r}}$ abundance indirectly feeds back to steady-state SOM pools (Fig. 5b), because we also assumed that the turnover of $\mathrm{MIC}_{\mathrm{r}}$ is greater than that of $\mathrm{MIC}_{\mathrm{K}}$. Thus, reducing the relative abundance of $\mathrm{MIC}_{\mathrm{r}}$ indirectly reduced inputs of microbial residues to SOM pools, reducing total soil C storage. Reductions in soil C storage associated with the kinetics of litter $\mathrm{C}$ mineralization, however, are distal to the production of microbial residues that build SOM in MIMICS. Instead, parameters like MGE and microbial turnover are proximal to the production of microbial biomass and exert a greater influence over soil $\mathrm{C}$ dynamics (Fig. 5).

Carbon substrates and microbial physiology likely determine the efficiency by which different microbial functional types convert assimilated $\mathrm{C}$ into microbial biomass (Sinsabaugh et al., 2013; Lipson et al., 2009; Pfeiffer et al., 2001; Russell and Cook, 1995). We explore this theory by decreasing the MGE of $\mathrm{MIC}_{\mathrm{r}}$ communities by $10 \%$ (see Lee and Schmidt, 2013). This modification concurrently reduces the relative abundance of the $\mathrm{MIC}_{\mathrm{r}}$ community by $7-14 \%$, with greater reductions in high-substrate quality environments (Fig. 5a). These results indicate that assumptions made about tradeoffs between microbial growth rates and MGE may be important in structuring competitive interactions between microbial functional types. The relative abundance of
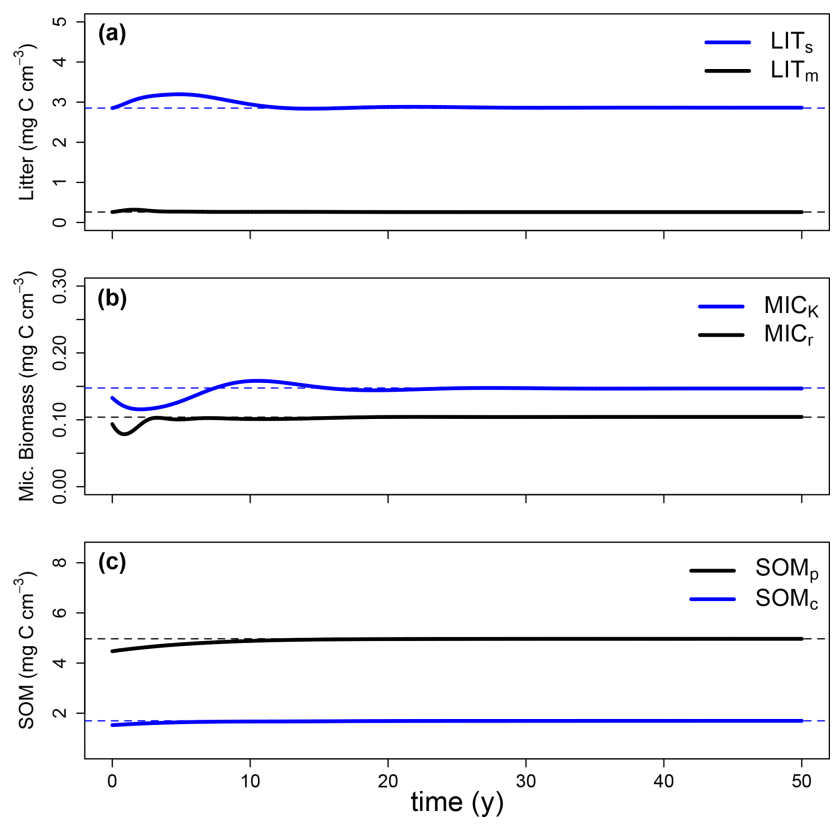

Figure 6. Temporal response of (a) litter, (b) microbial biomass, and (c) soil C pools to a $10 \%$ reduction of steady-state MIC and SOM pools at time zero of the experiment (solid lines). Steady-state pools were calculated for a hypothetical site at $15^{\circ} \mathrm{C}$, as described in the methods, and are indicated by dashed lines. Litter and microbial biomass pools oscillate following this perturbation, while SOM pools increase monotonically until they reach their steady state. The amplitude of the oscillation is comparable with results from Wang et al. (2014); however, the period of oscillation and the time required to return to steady-state values is shorter in this parameterization of MIMICS.

microbial functional types relates to the community physiological function, which in turn influences soil $\mathrm{C}$ dynamics. In this example, reducing the relative abundance of the $\mathrm{MIC}_{\mathrm{r}}$ community by reducing its MGE can either increase or decrease soil C storage (Fig. 5b). In low-quality resource environments $\left(f_{\mathrm{met}}<0.25\right)$, reducing $\mathrm{MIC}_{\mathrm{r}}$ abundance reduces rates of SOM turnover and can lead to modest increases in SOM pools by as much as $2 \%$. In high-quality resource environments $\left(f_{\text {met }}>0.25\right)$, reducing the relative abundance of $\mathrm{MIC}_{\mathrm{r}}$ communities reduces inputs of microbial residues to SOM pools with more than $3 \%$ declines in steady-state soil C storage.

Modifications that reduce the kinetic capacity and growth efficiency of the $\mathrm{MIC}_{\mathrm{r}}$ community reduce the relative abundance of this community. Shifts in community composition largely influence SOM dynamics via interactions with the production of microbial residues that govern the fate of $\mathrm{C}$ in MIMICS. Not surprisingly, increasing the microbial turnover of the $\mathrm{MIC}_{\mathrm{r}}$ community by $10 \%$ also reduces the relative abundance of this functional type by 6-18\% (Fig. 5a). This directly increases inputs of microbial residues to SOM pools and generally increases soil $\mathrm{C}$ storage, with greater SOC 
accumulation in clay-rich environments that stabilize microbial residues (Fig. 5b). Thus, in MIMICS we assume that microbial functional types can govern the fate of $\mathrm{C}$ substrates assimilated. Microbial growth efficiency and turnover are proximal to the production of microbial biomass and microbially derived inputs to SOM pools. Accordingly, these parameters have a larger influence on the relative abundance of microbial functional types and soil C stabilization.

As with other microbially explicit models, MIMICS produces an oscillatory response to perturbations of initial pool sizes (Figs. 3 and 6; Li et al. 2014; Wang et al. 2014). In MIMICS, only litter and microbial biomass pools oscillate, while SOM pools show a monotonic response. Total LIT and MIC pools increase from their steady-state conditions by as much as $11 \%$ and $3.1 \%$, respectively, and the magnitude of their oscillations decreases exponentially with time (Fig. 6). These results align with findings from Wang et al. (2014) that analyzed a three-pool model based on the same model structure applied in MIMICS (modified from Wieder et al., 2013). The frequency of the oscillation and time required to return to steady state is shorter in MIMICS than the threepool model analyzed by Wang et al. (2014), which could be due to differences in model structures or could be an artifact of model parameterizations. These results indicate that the additional complexity and number of non-linear terms that govern soil C turnover in MIMICS do not affect model stability, and may even reduce the frequency of oscillations in response to disturbance.

\section{Discussion}

We outline a framework for integrating litter quality, functional differences in microbial physiology, and the physical protection of microbial byproducts in forming stable SOM in a process-based numerical model (Fig. 1; Table 1). Our approach simulates observed climate and litter quality effects on average rates of leaf litter decomposition (Fig. 2), providing a robust validation for the MIMICS parameterizations governing the kinetics of litter decay. Moreover, the structure and parameterization of MIMICS better captures the acclimatization of soil C losses seen at Harvard Forest and elsewhere (Fig. 3; Melillo et al., 2002; Luo et al., 2001; Oechel et al., 2000). While initial results suggest MIMICS is a promising predictive tool, they also provide a framework for evaluating the microbial processes underlying SOM dynamics. Initial results from MIMICS suggest that soil $\mathrm{C}$ stabilization may be greatest in environments with high metabolic inputs and clay-rich soils (Fig. 4), results that align with recent experimental evidence and conceptual models of SOM formation that highlight the production and stabilization of microbial residues on mineral surfaces (Cortufo et al., 2013; Miltner et al., 2012; Kleber et al., 2011; Grandy and Neff, 2008; Marschner et al., 2008). Furthermore, our results suggest that proximal controls over the production of microbial biomass and residues, MGE and microbial turnover, provide an important mechanism by which microbial communities may influence SOM dynamics in mineral soils (Fig. 5).

Given the sensitivity of terrestrial $\mathrm{C}$ storage to changes in $\mathrm{C}$ turnover times (Friend et al., 2014; Todd-Brown et al., 2014; Arora et al., 2013; Jones et al., 2013;), improving the process-level representation of soil biogeochemistry models in environmental change remains a critical research priority. The Earth system models used to project future Ccycle feedbacks currently use soil biogeochemical models with structures and parameterizations similar to DAYCENT (Todd-Brown et al., 2013). Total soil C losses simulated by DAYCENT in response to experimental warming at Harvard Forest are three times greater than those projected by MIMCS after 20 years (Fig. 3b). Moreover, MIMICS seems to better capture observed attenuation of soil $\mathrm{C}$ losses with prolonged warming, while allowing us to begin exploring theoretical interactions between substrate quality, microbial community abundance, and the formation of stable SOM. The extent to which microbial physiological variation and response to environmental changes can be constrained by observations remains uncertain, especially for MGE and microbial turnover, but overcoming this technical challenge may be critical to resolving the potential effects of microbial functional diversity in soil biogeochemical models.

While MIMICS provides insights into the interaction between SOM dynamics and microbial physiology, it also presents a platform for evaluating the key differences between traditional and microbial modeling approaches (summarized in Table 2). Traditional soil biogeochemistry models simulate the turnover of SOM based on the implicit representation of microbial activity (Schnitzer and Montreal, 2011; Berg and McClaugherty, 2008). Soil C turnover in these models is typically parameterized via first-order kinetics and modified by environmental scalars (Wieder et al., 2014; Todd Brown et al., 2013), an approach that overlooks potential warming-induced substrate limitation and/or thermal acclimation of soil microbial communities (Fig. 3; Bradford et al., 2008; Kirshbaum 2004; Luo et al., 2001). In microbially explicit models, like MIMICS, substrate concentration partially determines rates of $\mathrm{C}$ turnover (Eq. 1; see also Wieder et al., 2013, and Allison et al., 2010). Initially, warming accelerates SOM decomposition rates through accelerated kinetics, but as the concentration of substrate pools declines, so do rates of soil $\mathrm{C}$ loss. Future investigations into the potential acclimation of microbial physiological traits and/or shifts in community abundance present a unique opportunity to evaluate and refine our mechanistic understanding of soil microbial and biogeochemical responses to environmental perturbations. For example, observations show decreases in microbial biomass and evidence of microbial community shifts with experimental warming (Bradford et al., 2008; Frey et al., 2008). Rigorous evaluation of our processlevel representation can improve our confidence projections of soil $\mathrm{C}$ feedbacks and should include cross-site analyses 
and syntheses that look at soil biogeochemical and microbial responses to experimental manipulations across environmental and edaphic gradients.

\subsection{Litter inputs and SOM formation}

The number of litter inputs is positively related to steadystate SOM pool sizes in traditional biogeochemistry models (Todd-Brown et al., 2013). By contrast, the quantity of litter inputs is completely unrelated to steady-state SOM pool size in microbially explicit models. This feature appears to be characteristic of microbially explicit models ( $\mathrm{Li}$ et al., 2014; Wang et al., 2014). Instead, litter quantity determines the size of microbial biomass pools, in agreement with observational data (Fierer et al., 2009). In MIMICS, larger microbial biomass pools increase input rates of microbial residues to SOM pools, but they also accelerate rates of $\mathrm{C}$ turnover in a "priming effect". This phenomenon occurs when new $\mathrm{C}$ inputs result in the accelerated turnover of native SOM (Phillips et al., 2011; Kuzyakov, 2010). Recognizing the potential for priming to have a disproportionately strong effect on SOM dynamics in microbially explicit models, we created a physically protected SOM pool (Fig. 1). This provides a mechanism whereby increasing litter inputs could increase inputs of microbial residues to SOM pools to a greater extent than larger microbial biomass pools could mineralize extant $\mathrm{SOM}$, at least in clay-rich soils. However, microbial biomass still directly affects inputs and losses from SOM, suggesting that MIMICS likely overemphasizes the role of biological processes in what should be physically dominant SOM stabilization mechanisms. How frequently priming decreases SOM with increasing litter inputs is unknown, but there is an increasing number of studies showing that increases in litter inputs do not increase or may even decrease soil C (Sulzman et al., 2005; Nadelhoffer et al., 2004; Bowden et al., 2014; Lajtha et al., 2014, but see also Leff et al., 2012). While the relationships between $\mathrm{C}$ inputs, microbial biomass pools, and SOM are a controversial element of microbially explicit models and require clarifications, they do have their basis in both experimental evidence and theory.

In traditional models, increasing litter quality typically causes declines in soil $\mathrm{C}$ storage, with greater partitioning into pools with faster turnover times (Wieder et al., 2014; Schimel et al., 1994). As parameterized in MIMICS, increasing the chemical quality of litter inputs increases the relative abundance of the copiotrophic microbial community $\left(\mathrm{MIC}_{\mathrm{r}}\right)$ with faster kinetics (Table 1; Fig. 5a), a result that qualitatively aligns with observations (Waring et al., 2013; Nemergut et al., 2010; Rousk and Bååth, 2007). Our results indicate that the combined effects of accelerated litter turnover and increasing microbial inputs on SOM depend on soil texture, with maximum soil $\mathrm{C}$ storage occurring in high-clay soils receiving high-quality litter inputs (Fig. 4). These divergent projections between traditional and microbial models highlight the importance of considering potential inter- actions between microbial physiology and the physical soil environment.

Explicit representation of the physical protection of SOM in MIMICS provides a mechanism to form stable SOM via mineral stabilization of microbial byproducts (Six et al., 2002; Sollins et al., 1996). A high turnover of $\mathrm{MIC}_{\mathrm{r}} \mathrm{com}-$ munities can thus actually build stable SOM in resource-rich environments when those microbial byproducts are physically stabilized in finely textured soils (Fig. 4). Currently, we combine the physical protection mechanisms of aggregation and mineral associations (Grandy and Robertson, 2007; Mikutta et al., 2006; Six et al., 2002; Hassink, 1997) in the same functional pool $\left(\mathrm{SOM}_{\mathrm{p}}\right.$; Fig. 1). Given the potential differences in the long-term stabilization of various protection mechanisms, further analyses are needed to evaluate the model structures and parameterizations to simulate diverse stabilization mechanisms better across larger spatial and temporal scales.

\subsection{Microbial physiology}

Microbial physiological traits related to growth and biomass production are key elements in determining input rates of microbial residues to SOM. The deficit of empirical data relating soil $\mathrm{C}$ stabilization to MGE and microbial turnover presents challenges to moving beyond these theoretical concepts; however, MIMICS introduces a framework to explore how microbial physiological tradeoffs may influence relative community abundance and soil $\mathrm{C}$ dynamics. $\mathrm{Al}$ though highly reductionist, simplifying the metabolic and life-history strategies of below-ground communities into broad categories relating to microbial physiology provides a tractable path forward to begin exploring how microbial community structure and abundance may affect soil biogeochemical processes (Miki et al., 2010). While the temperature responses of Michaelis-Menten kinetics are based on observational data (German et al., 2012), the model presented here provides numerous avenues to explore how less well-defined microbial characteristics respond to the physical and chemical soil environment and how changes in those responses may mediate biogeochemical processes. For example, we have made certain assumptions about the effectiveness of microbial functional types in mineralizing different $\mathrm{C}$ substrate pools (Table 1). While broadly based on microbial physiological theory (Fierer et al., 2007), these assumptions establish competitive interactions between copiotrophic and oligotrophic microbial communities that structure the relative abundance of microbial functional types at steady state (Fig. 5).

Key physiological parameters in MIMICS include the Michaelis-Menten kinetics of substrate mineralization $\left(V_{\max }\right.$ and $K_{\mathrm{m}}$ ), the efficiency by which microbial communities turn $\mathrm{C}$ substrates into biomass (MGE), and the rate of microbial turnover $(\tau)$. The importance of microbial physiology for determining soil $\mathrm{C}$ dynamics remains uncertain, 
Table 2. Main effects of major model components in traditional soil biogeochemical models based on theories of chemical recalcitrance and the MIMICS microbial model.

\begin{tabular}{lll}
\hline Component & Traditional model & MIMICS model \\
\hline Litter quality & $\begin{array}{l}\text { Determines partitioning to pools with differ- } \\
\text { ent turnover times. SOM pools decline with in- } \\
\text { creasing } f_{\text {met }}\end{array}$ & $\begin{array}{l}\text { Determines partitioning to LIT pools and the relative abun- } \\
\text { dance of MIC communities. Variable SOM pool response to } \\
f_{\text {met. }}\end{array}$ \\
\hline Litter quantity & Determines SOM pool size. & Determines MIC pool size. \\
\hline Soil texture & $\begin{array}{l}\text { Modulates turnover constants and partitioning } \\
\text { of SOM between pools. No explicit representa- } \\
\text { tion of physical protection. }\end{array}$ & $\begin{array}{l}\text { Explicitly represents physical protection of SOM. Provides } \\
\text { a mechanism for microbial byproducts to build stable SOM. }\end{array}$ \\
\hline Reaction kinetics & $\begin{array}{l}\text { Environmentally sensitive. Determines turnover } \\
\text { of C pools. }\end{array}$ & $\begin{array}{l}\text { Temperature sensitive. Along with MIC pool size deter- } \\
\text { mines substrate turnover. Structures competitive dynamics } \\
\text { between MIC } \text { and MIC }\end{array}$ \\
\hline MGE & $\begin{array}{l}\text { Determines fraction of C lost between pool } \\
\text { transfers, no effect on rates of C mineralization. }\end{array}$ & $\begin{array}{l}\text { Determines fraction of C lost in transfers to MIC pools and } \\
\text { MIC pool size. Thus, MGE affects rates of C mineralization } \\
\text { and competitive dynamics between MIC } \text { and MIC }\end{array}$ \\
\hline \begin{tabular}{l} 
Implicitly simulated as part of reaction kinetics. \\
\hline
\end{tabular} & $\begin{array}{l}\text { Explicitly simulated. Determines microbial control over } \\
\text { SOM formation in mineral soils. }\end{array}$ \\
\hline
\end{tabular}

especially in mineral soils where physical access to $\mathrm{C}$ substrates, and not microbial catabolic potential, limits rates of SOM mineralization (Schimel and Schaeffer, 2012). Thus, the extent to which physiological differences between microbial functional groups determine the fate of $\mathrm{C}$ remains speculative (Cotrufo et al., 2013; Schimel and Schaeffer, 2012), but MIMICS suggests that proximal factors controlling the production and turnover of microbial biomass (MGE and $\tau$ ) will mediate soil C dynamics (Fig. 5). These characteristics of microbially explicit models show similarities to key drivers determining steady-state SOM pools in traditional models (environmentally sensitive turnover rates, the number of litter inputs and MGE; Todd-Brown et al., 2013, Xia et al., 2013), although these parameters can elicit contrasting responses in different modeling frameworks.

In traditional and microbial models, MGE influences soil biogeochemical responses to perturbations by determining the fraction of assimilated $\mathrm{C}$ that enters receiver pools, an observation that initiated a surge of interest in quantifying and understanding factors that influence MGE (Frey et al., 2013; Sinsabaugh et al., 2013; Tucker et al., 2013; Manzoni et al., 2012; Allison et al., 2010; Bradford et al., 2008). Although MGE is typically fixed in traditional models (Manzoni et al., 2012), reducing MGE increases the fraction of assimilated $\mathrm{C}$ lost to heterotrophic respiration rates without modifying rates of $\mathrm{C}$ mineralization from donor pools (Frey et al., 2013; Tucker et al., 2013), causing an overall reduction in SOM pools (Fig. 3). By contrast, MGE and microbial turnover regulate both pool size and rates of litter and SOM turnover in microbially explicit models. Thus, reducing MGE also increases the fraction of mineralized $\mathrm{C}$ lost to heterotrophic respiration and reduces the size of micro- bial biomass pools in MIMICS. Reducing microbial biomass pools concurrently slows rates of substrate mineralization (Eq. 1) and may result in no net change in steady-state SOM pool size (Fig. 3a). Changes in MGE may affect steady-state SOM pools by influencing the relative abundance of microbial functional types (Fig. 5), which determines both microbial turnover and SOM mineralization kinetics. This feature is absent in microbial models lacking explicit microbial functional types (Wieder et al., 2013), and shows that understanding the response of MGE to perturbations may be important for resolving questions of microbial competition, physiological tradeoffs, community composition and soil biogeochemical function on multiple scales.

Physiological differences in catabolic potential between microbial functional types become less important in mineral soils where soil texture determines the half-saturation constant for SOM mineralization (Table 1). Instead, the allocation of microbial biomass to the chemically and physically protected pools becomes more important in determining the microbial influence on SOM dynamics (Schimel and Schaeffer, 2012; Fig. 5). In sandy soils, with low physical protection of SOM, microbial communities have easier physical access to SOM pools and biochemical protection is more important in stabilizing SOM. In MIMICS, low litter quality environments favor oligotrophic microbial communities, which have slower kinetics and turnover. While $\mathrm{MIC}_{\mathrm{K}}$ still allocate $\mathrm{C}$ to the physically protected pool, the combination of litter chemical recalcitrance and lower microbial kinetics results in more litter byproducts entering the chemically protected pool. This leads to greater $\mathrm{C}$ storage in low-clay soils receiving lowquality litter inputs (Fig. 4). With increasing clay content, microbial access to $\mathrm{C}$ become restricted as physical protection 
increases. Accordingly, soil C storage is maximized in highclay soils that have greater microbial turnover that is allocated to physically protected pools (i.e., high-quality litter inputs).

These examples highlight the importance of $\tau$ in determining the amount of microbial control over soil $\mathrm{C}$ cycling, although our inability to quantify the flow of $\mathrm{C}$ from microbes into SOM (Simpson et al., 2007), and rates of microbial growth and turnover (Blagodatskaya and Kuzyakov, 2013; Rousk and Bååth, 2011; Blazewicz and Schwartz, 2011), limits numerical approaches to simulating microbial physiology (sensu Elliott et al., 1996). Thus, estimating microbial turnover and its potential response to the soil environment remains a huge source of uncertainty in microbial models that has not been readily assessed with current experimental techniques.

Although our aim with this paper is to document the theoretical underpinnings that generated the model assumptions and structures that are applied in MIMICS, we briefly discuss the broader implications of applying this type of model in global change scenarios. Microbially explicit models produce notably divergent responses to perturbations when compared with traditional soil biogeochemistry models (e.g., Wieder et al. 2013; Wang et al. 2014). For example, temperature-sensitive reaction kinetics govern rates of soil C turnover in both classes of models, so that warming temperatures drive losses in soil C. Different assumptions about the temperature sensitivity of SOM, model structures, and model parameterizations (Todd-Brown et al. 2013a; Davidson and Janssens 2006; Jones et al. 2005) drive large discrepancies in model projections of soil $\mathrm{C}$ responses to warming temperatures (Todd-Brown et al. 2013b). These effects are compounded in microbially explicit models like MIMICS, because the accelerated SOM turnover associated with more rapid kinetics also builds more microbial biomass, which further accelerates decomposition rates (Eq. 1). These dynamics may be dampened if the effects of temperature-driven kinetics are offset by concurrent declines in microbial biomass, either through reduced microbial efficiency or higher microbial turnover (Wang et al. 2014; Wieder et al., 2013). Despite recent advances (sensu Frey et al., 2013), we stress that our theoretical and empirical understanding of these dynamics remains poorly quantified, especially across environmental gradients. We hypothesize that spatiotemporal variation in microbial community dynamics and their interaction with the physio-chemical soil environment will have strong sitelevel effects on soil $\mathrm{C}$ response warming. MIMICS presents a framework to begin generating and testing these hypotheses.

While microbially explicit models like MIMICS present advancements in our ability to represent contemporary ecological theory, their numerical application can also generate oscillatory behaviors that are not desirable in models used on global scales ( $\mathrm{Li}$ et al. 2014; Wang et al. 2014). The oscillations evident in Fig. 2 are generated by temperature variability and are not evident when forcing the model with constant soil temperature (W. Wieder, unpublished data 2014); however, preliminary results indicate that MIMICS has an oscillatory behavior similar to the three-pool model analyzed by Wang and others (2014) (Figs. 3 and 6). Our aim with MIMICS, however, is to marry the strengths of microbially implicit and microbially explicit approaches, and further evaluation is needed to determine which model structure and parameterizations are needed to improve our representation of contemporary soil biogeochemical theory and the predictability of microbially driven soil $\mathrm{C}$ dynamics on continental and global scales.

Evaluating the patterns and processes that emerge from microbially explicit models poses significant challenges and opportunities. In particular, MIMICS would benefit from a stronger theoretical and empirical understanding of microbial physiological responses to perturbations. A growing body of literature documents site-level microbial community shifts and physiological responses to environmental change drivers (Lee and Schmidt 2013; Stone et al., 2012; Dijkstra et al., 2011; Manzoni et al., 2011; Nemergut et al., 2010; Carney et al., 2007; Waldrop et al., 2004). Metagenomic analyses may provide insight into the relative abundances of microbial functional types and their associated physiological traits (Portillo et al. 2013; Verberk et al. 2013; Fierer et al. 2012). Pairing microbial data that are sampled across wide geographic gradients (Ramirez et al., 2012) with meta-analyses of ecosystem responses to perturbations (Janssens et al., 2010, Liu and Greaver, 2010) could provide useful observational constraints and present broad targets that models should be expected to replicate. Moreover, data-rich observations from global change experiments (e.g., Sierra et al. 2012) provide additional resources to evaluate model assumptions, structures, and parameterizations. Confidence in model projections can be improved if parameterizations for microbial physiology traits across gradients or in response to perturbations draw on robust empirical relationships. This goal seems feasible for parameterizations of Michaelis-Menten kinetics and MGE (Frey et al., 2013; Lee and Schmidt 2013; German et al., 2012). Developing similar empirical relationships to resolve community effects on the fate of microbial turnover products remains a challenge, although new approaches may offer key insights (e.g., Aanderud and Lennon, 2011; Blazewicz and Schwartz, 2011). The degree to which microbial communities affect soil $\mathrm{C} \mathrm{dy-}$ namics in mineral soils (Schimel and Schaeffer, 2012) likely depend on such data.

MIMICS provides a tractable test bed for exploring the implementation of microbially based soil biogeochemical concepts across scales. Our new microbially based model, MIMICS, demonstrates how to incorporate the effects of below-ground metabolic and biological diversity into biogeochemical cycles through the explicit representation of microbial functional types, parameterized by functional tradeoffs in physiological strategies. We also introduce a framework for simulating the effects of the litter chemical quality and 
physical stabilization of SOM in microbially explicit models. Further model developments should include soil environmental drivers that modify rates of biogeochemical processes and microbial community composition (e.g., soil moisture, oxygen availability, nitrogen availability, soil $\mathrm{pH}$, land management practices, etc.). These developments demand collaboration between observational and modeling communities, and will benefit from the synthesis of data sets that can be used to parameterize and evaluate processes simulated across gradients and in response to perturbations. Despite these challenges, we see the potential for significant steps forward in advancing and refining our theoretical understanding of soil biogeochemical cycles and the implementation of that theory in processed-based models.

\section{The Supplement related to this article is available online at doi:10.5194/bg-11-3899-2014-supplement.}

Acknowledgements. The National Center for Atmospheric Research is sponsored by the National Science Foundation. This work was supported by National Science Foundation grant AGS1020767. Financial support for A. S. Grandy was provided by the United States Department of Agriculture Soil Processes program, grant \#2009-65107-05961. Financial support was also provided by the US DOE Office of Science (DE-FCO2-07ER64494) and the Office of Energy Efficiency and Renewable Energy (DE-ACO5-76RL01830) funding for the Great Lakes Bioenergy Research Center. Finally, C. M. Kallenbach was funded by the NSF (BIO-1311501) and the USDA-NIFA (2014-67011-21569). Significant funding for data accessed through Climate and Hydrology Database Projects was provided by the National Science Foundation Long-Term Ecological Research program and the USDA Forest Service.

Edited by: S. Zaehle

\section{References}

Aanderud, Z. T. and Lennon, J. T.: Validation of heavy-water stable isotope probing for the characterization of rapidly responding soil bacteria, Appl. Environ. Microbiol., 77, 4589-4596, doi:10.1128/aem.02735-10, 2011.

Adair, E. C., Parton, W. J., Del Grosso, S. J., Silver, W. L., Harmon, M. E., Hall, S. A., Burkes, I. C., and Hart, S. C.: Simple three-pool model accurately describes patterns of long-term litter decomposition in diverse climates, Global Change Biol., 14, 2636-2660, 2008.

Allison, S. D., Wallenstein, M. D., and Bradford, M. A.: Soil-carbon response to warming dependent on microbial physiology, Nat. Geosci., 3, 336-340, doi:10.1038/ngeo846, 2010.

Allison, S. D.: A trait-based approach for modelling microbial litter decomposition, Ecol. Lett., 15, 1058-1070, doi:10.1111/j.14610248.2012.01807.x, 2012.
Arora, V. K., Boer, G. J., Friedlingstein, P., Eby, M., Jones, C. D., Christian, J. R., Bonan, G., Bopp, L., Brovkin, V., Cadule, P., Hajima, T., Ilyina, T., Lindsay, K., Tjiputra, J. F., and $\mathrm{Wu}, \mathrm{T}$.: Carbon-concentration and carbon-climate feedbacks in cmip5 earth system models, J. Climate, 26, 5289-5314, doi:10.1175/jcli-d-12-00494.1, 2013.

Bardgett, R. D., Freeman, C., and Ostle, N. J.: Microbial contributions to climate change through carbon cycle feedbacks, The ISME Journal, 2, 805-814, 2008.

Beardmore, R. E., Gudelj, I., Lipson, D. A., and Hurst, L. D.: Metabolic trade-offs and the maintenance of the fittest and the flattest, Nature, 472, 342-346, 2011.

Berg, B. and McClaugherty, C.: Plant litter: Decomposition, humus formation, carbon sequestration, 2nd ed., Springer, 338 pp., 2008.

Blagodatskaya, E. and Kuzyakov, Y.: Active microorganisms in soil: Critical review of estimation criteria and approaches, Soil Biol. Biochem., 67, 192-211, 2013.

Blazewicz, S. and Schwartz, E.: Dynamics of ${ }^{18} \mathrm{O}$ incorporation from $\mathrm{H}_{2}^{18} \mathrm{O}$ into soil microbial DNA, Microb. Ecol., 61, 911916, doi:10.1007/s00248-011-9826-7, 2011.

Bol, R., Poirier, N., Balesdent, J., and Gleixner, G.: Molecular turnover time of soil organic matter in particle-size fractions of an arable soil, Rapid. Commun. Mass. Sp., 23, 2551-2558, doi:10.1002/rcm.4124, 2009.

Bonan, G.: Ecological climatology: Concepts and applications, 2 ed., Cambridge University Press, Cambridge, UK, New York, 550 pp., 2008.

Bonan, G. B., Oleson, K. W., Fisher, R. A., Lasslop, G., and Reichstein, M.: Reconciling leaf physiological traits and canopy flux data: Use of the try and fluxnet databases in the community land model version 4, J. Geophys. Res.-Biogeo., 117, G02026, doi:10.1029/2011jg001913, 2012.

Bonan, G. B., Hartman, M. D., Parton, W. J., and Wieder, W. R.: Evaluating litter decomposition in earth system models with long-term litterbag experiments: An example using the community land model version 4 (clm4), Global Change Biol., 19, $957-$ 974, doi:10.1111/gcb.12031, 2013.

Bowden, R. D., Deem, L., Plante, A. F., Peltre, C. m., Nadelhoffer, K., and Lajtha, K.: Litter input controls on soil carbon in a temperate deciduous forest, Soil Sci. Soc. Am. J., doi:10.2136/sssaj2013.09.0413nafsc, 2014.

Bradford, M. A., Davies, C. A., Frey, S. D., Maddox, T. R., Melillo, J. M., Mohan, J. E., Reynolds, J. F., Treseder, K. K., and Wallenstein, M. D.: Thermal adaptation of soil microbial respiration to elevated temperature, Ecol. Lett., 11, 1316-1327, doi:10.1111/j.1461-0248.2008.01251.x, 2008.

Brovkin, V., van Bodegom, P. M., Kleinen, T., Wirth, C., Cornwell, W., Cornelissen, J. H. C., and Kattge, J.: Plant-driven variation in decomposition rates improves projections of global litter stock distribution, Biogeosciences, 9, 565-576, doi:10.5194/bg-9-5652012, 2012.

Carney, K. M., Hungate, B. A., Drake, B. G., and Megonigal, J. P.: Altered soil microbial community at elevated $\mathrm{CO}_{2}$ leads to loss of soil carbon, P. Natl. Acad. Sci., 104, 4990-4995, doi:10.1073/pnas.0610045104, 2007.

Conant, R. T., Ryan, M. G., Ågren, G. I., Birge, H. E., Davidson, E. A., Eliasson, P. E., Evans, S. E., Frey, S. D., Giardina, C. P., Hopkins, F. M., Hyvönen, R., Kirschbaum, M. U. F., Lavallee, J. 
M., Leifeld, J., Parton, W. J., Megan Steinweg, J., Wallenstein, M. D., Martin Wetterstedt, J. Å., and Bradford, M. A.: Temperature and soil organic matter decomposition rates - synthesis of current knowledge and a way forward, Global Change Biol., 17, 3392-3404, doi:10.1111/j.1365-2486.2011.02496.x, 2011.

Cotrufo, M. F., Wallenstein, M. D., Boot, C. M., Denef, K., and Paul, E.: The microbial efficiency-matrix stabilization (mems) framework integrates plant litter decomposition with soil organic matter stabilization: Do labile plant inputs form stable soil organic matter?, Global Change Biol., 19, 988-995, doi:10.1111/gcb.12113, 2013.

Currie, W. S., Harmon, M. E., Burke, I. C., Hart, S. C., Parton, W. J., and Silver, W.: Cross-biome transplants of plant litter show decomposition models extend to a broader climatic range but lose predictability at the decadal time scale, Global Change Biol., 16, 1744-1761, doi:10.1111/j.1365-2486.2009.02086.x, 2010.

Davidson, E. A., and Janssens, I. A.: Temperature sensitivity of soil carbon decomposition and feedbacks to climate change, Nature, 440, 165-173, doi:10.1038/nature04514, 2006.

del Giorgio, P. A., and Cole, J. J.: Bacterial growth efficiency in natural aquatic systems, Annu. Rev. Ecol. Syst., 29, 503-541, doi:10.1146/annurev.ecolsys.29.1.503, 1998.

Dethlefsen, L. and Schmidt, T. M.: Performance of the translational apparatus varies with the ecological strategies of bacteria, J. Bacteriol., 189, 3237-3245, doi:10.1128/jb.01686-06, 2007.

Dijkstra, P., Thomas, S. C., Heinrich, P. L., Koch, G. W., Schwartz, E., and Hungate, B. A.: Effect of temperature on metabolic activity of intact microbial communities: Evidence for altered metabolic pathway activity but not for increased maintenance respiration and reduced carbon use efficiency, Soil Biol. Biochem., 43, 2023-2031, 2011.

Dungait, J. A. J., Hopkins, D. W., Gregory, A. S., and Whitmore, A. P.: Soil organic matter turnover is governed by accessibility not recalcitrance, Global Change Biol., 18, 1781-1796, 1doi:0.1111/j.1365-2486.2012.02665.x, 2012.

Ehleringer, J. R. and Field, C. B.: Scaling physiological processes: Leaf to globe, edited by: Roy, J., Academic Press Inc, San Diego, CA, 388 pp., 1993.

Elliott, E., Paustian, K., and Frey, S.: Modeling the measurable or measuring the modelable: A hierarchical approach to isolating meaningful soil organic matter fractionations, in: Evaluation of soil organic matter models, edited by: Powlson, D., Smith, P., and Smith, J., Nato asi series, Springer Berlin Heidelberg, 161179, 1996

FAO, IIASA, ISRIC, ISSCAS, and JRC: Harmonized world soil database (version 1.2), in, 1.2 ed., edited by: FAO, Rome, Italy and IIASA, Laxenburg, Austria, 2012.

Fierer, N., Bradford, M. A., and Jackson, R. B.: Toward an ecological classification of soil bacteria, Ecology, 88, 1354-1364, doi:10.1890/05-1839, 2007.

Fierer, N., Strickland, M. S., Liptzin, D., Bradford, M. A., and Cleveland, C. C.: Global patterns in belowground communities, Ecol. Lett., 12, 1238-1249, doi:10.1111/j.14610248.2009.01360.x, 2009.

Fierer, N., Lauber, C. L., Ramirez, K. S., Zaneveld, J., Bradford, M. A., and Knight, R.: Comparative metagenomic, phylogenetic and physiological analyses of soil microbial communities across nitrogen gradients, ISME J., 6, 1007-1017, 2012a.
Fierer, N., Leff, J. W., Adams, B. J., Nielsen, U. N., Bates, S. T., Lauber, C. L., Owens, S., Gilbert, J. A., Wall, D. H., and Caporaso, J. G.: Cross-biome metagenomic analyses of soil microbial communities and their functional attributes, P. Natl. Acad. Sci., 109, 21390-21395, doi:10.1073/pnas.1215210110, 2012b.

Fontaine, S. and Barot, S.: Size and functional diversity of microbe populations control plant persistence and long-term soil carbon accumulation, Ecol. Lett., 8, 1075-1087, doi:10.1111/j.14610248.2005.00813.x, 2005.

Frey, S. D., Drijber, R., Smith, H., and Melillo, J.: Microbial biomass, functional capacity, and community structure after 12 years of soil warming, Soil Biol. Biochem., 40, 2904-2907, 2008.

Frey, S. D., Lee, J., Melillo, J. M., and Six, J.: The temperature response of soil microbial efficiency and its feedback to climate, Nat. Clim. Change, 3, 395-398, doi:10.1038/nclimate1796, 2013.

Friedlingstein, P., Cox, P., Betts, R., Bopp, L., von Bloh, W., Brovkin, V., Cadule, P., Doney, S., Eby, M., Fung, I., Bala, G., John, J., Jones, C., Joos, F., Kato, T., Kawamiya, M., Knorr, W., Lindsay, K., Matthews, H. D., Raddatz, T., Rayner, P., Reick, C., Roeckner, E., Schnitzler, K. G., Schnur, R., Strassmann, K., Weaver, A. J., Yoshikawa, C., and Zeng, N.: Climate-carbon cycle feedback analysis: Results from the c4mip model intercomparison, J. Climate, 19, 3337-3353, doi10.1175/jcli3800.1, 2006.

Friend, A. D., Lucht, W., Rademacher, T. T., Keribin, R., Betts, R., Cadule, P., Ciais, P., Clark, D. B., Dankers, R., Falloon, P. D., Ito, A., Kahana, R., Kleidon, A., Lomas, M. R., Nishina, K., Ostberg, S., Pavlick, R., Peylin, P., Schaphoff, S., Vuichard, N., Warszawski, L., Wiltshire, A., and Woodward, F. I.: Carbon residence time dominates uncertainty in terrestrial vegetation responses to future climate and atmospheric $\mathrm{CO}_{2}$, P. Natl. Acad. Sci., 111, 3280-3285, doi:10.1073/pnas.1222477110, 2014.

German, D. P., Marcelo, K. R. B., Stone, M. M., and Allison, S. D.: The michaelis-menten kinetics of soil extracellular enzymes in response to temperature: A cross-latitudinal study, Glob. Change Biol., 18, 1468-1479, doi:10.1111/j.1365-2486.2011.02615.x, 2012.

Gholz, H. L., Wedin, D. A., Smitherman, S. M., Harmon, M. E., and Parton, W. J.: Long-term dynamics of pine and hardwood litter in contrasting environments: Toward a global model of decomposition, Glob. Change Biology, 6, 751-765, 2000.

Goldfarb, K. C., Karaoz, U., Hanson, C. A., Santee, C. A., Bradford, M. A., Treseder, K. K., Wallenstein, M. D., and Brodie, E. L.: Differential growth responses of soil bacterial taxa to carbon substrates of varying chemical recalcitrance, Front. Microbiol., 2, doi:10.3389/fmicb.2011.00094, 2011.

Grandy, A. S. and Robertson, G. P.: Land-use intensity effects on soil organic carbon accumulation rates and mechanisms, Ecosystems, 10, 59-74, doi:10.1007/s10021-006-9010-y, 2007.

Grandy, A. S. and Neff, J. C.: Molecular c dynamics downstream: The biochemical decomposition sequence and its impact on soil organic matter structure and function, Sci. Total Environ., 404, 297-307, doi:10.1016/j.scitotenv.2007.11.013, 2008.

Grandy, A. S., Strickland, M. S., Lauber, C. L., Bradford, M. A., and Fierer, N.: The influence of microbial communities, management, and soil texture on soil organic matter chemistry, Geoderma, 150, 278-286, 2009. 
Harmon, M. E., Silver, W. L., Fasth, B., Chen, H. U. A., Burke, I. C., Parton, W. J., Hart, S. C., Currie, W. S., and Lidet: Longterm patterns of mass loss during the decomposition of leaf and fine root litter: An intersite comparison, Global Change Biol., 15, 1320-1338, doi:10.1111/j.1365-2486.2008.01837.x, 2009.

Harmon, M. E.: Lter intersite fine litter decomposition experiment (lidet), 1990 to 2002, Long-term ecological research, edited by: Bank, F. S. D., Corvallis, OR., 2013.

Hassink, J.: The capacity of soils to preserve organic $\mathrm{c}$ and $\mathrm{n}$ by their association with clay and silt particles, Plant. Soil, 191, 77-87, doi:10.1023/a:1004213929699, 1997.

Heckman, K., Grandy, A. S., Gao, X., Keiluweit, M., Wickings, K., Carpenter, K., Chorover, J., and Rasmussen, C.: Sorptive fractionation of organic matter and formation of organo-hydroxyaluminum complexes during litter biodegradation in the presence of gibbsite, Geochim. Cosmochim. Ac., 121, 667-683, 2013.

Hugelius, G., Tarnocai, C., Broll, G., Canadell, J. G., Kuhry, P., and Swanson, D. K.: The northern circumpolar soil carbon database: Spatially distributed datasets of soil coverage and soil carbon storage in the northern permafrost regions, Earth Syst. Sci. Data, 5, 3-13, doi:10.5194/essd-5-3-2013, 2013.

Janssens, I. A., Dieleman, W., Luyssaert, S., Subke, J. A., Reichstein, M., Ceulemans, R., Ciais, P., Dolman, A. J., Grace, J., Matteucci, G., Papale, D., Piao, S. L., Schulze, E. D., Tang, J., and Law, B. E.: Reduction of forest soil respiration in response to nitrogen deposition, Nat. Geosci., 3, 315-322, doi:10.1038/ngeo844, 2010.

Jastrow, J., Amonette, J., and Bailey, V.: Mechanisms controlling soil carbon turnover and their potential application for enhancing carbon sequestration, Clim. Change, 80, 5-23, doi:10.1007/s10584-006-9178-3, 2007.

Jenkinson, D. S., Adams, D. E., and Wild, A.: Model estimates of co2 emissions from soil in response to global warming, Nature, 351, 304-306, 1991.

Jobbágy, E. G. and Jackson, R. B.: The vertical distribution of soil organic carbon and its relation to climate and vegetation, Ecological Applications, 10, 423-436, doi:10.1890/10510761(2000)010[0423:TVDOSO]2.0.CO;2, 2000.

Jones, C., McConnell, C., Coleman, K., Cox, P., Falloon, P., Jenkinson, D., and Powlson, D.: Global climate change and soil carbon stocks; predictions from two contrasting models for the turnover of organic carbon in soil, Global Change Biol., 11, 154-166, doi:10.1111/j.1365-2486.2004.00885.x, 2005.

Jones, C., Robertson, E., Arora, V., Friedlingstein, P., Shevliakova, E., Bopp, L., Brovkin, V., Hajima, T., Kato, E., Kawamiya, M., Liddicoat, S., Lindsay, K., Reick, C. H., Roelandt, C., Segschneider, J., and Tjiputra, J.: Twenty-first-century compatible $\mathrm{CO}_{2}$ emissions and airborne fraction simulated by cmip5 earth system models under four representative concentration pathways, J. Climate, 26, 4398-4413, doi:10.1175/jcli-d-12-00554.1, 2013.

Jones, C. D., Cox, P., and Huntingford, C.: Uncertainty in climate-carbon-cycle projections associated with the sensitivity of soil respiration to temperature, Tellus B, 55, 642-648, doi:10.1034/j.1600-0889.2003.01440.x, 2003.

Kaiser, M., Walter, K., Ellerbrock, R. H., and Sommer, M.: Effects of land use and mineral characteristics on the organic carbon content, and the amount and composition of na-pyrophosphatesoluble organic matter, in subsurface soils, Europ. J. Soil Sci., 62, 226-236, doi:10.1111/j.1365-2389.2010.01340.x, 2011.
Kattge, J., Díaz, S., Lavorel, S., Prentice, I. C., Leadley, P., Bönisch, G., Garnier, E., Westoby, M., Reich, P. B., Wright, I. J., Cornelissen, J. H. C., Violle, C., Harrison, S. P., Van Bodegom, P. M., Reichstein, M., Enquist, B. J., Soudzilovskaia, N. A., Ackerly, D. D., Anand, M., Atkin, O., Bahn, M., Baker, T. R., Baldocchi, D., Bekker, R., Blanco, C. C., Blonder, B., Bond, W. J., Bradstock, R., Bunker, D. E., Casanoves, F., Cavender-Bares, J., Chambers, J. Q., Chapin Iii, F. S., Chave, J., Coomes, D., Cornwell, W. K., Craine, J. M., Dobrin, B. H., Duarte, L., Durka, W., Elser, J., Esser, G., Estiarte, M., Fagan, W. F., Fang, J., FernándezMéndez, F., Fidelis, A., Finegan, B., Flores, O., Ford, H., Frank, D., Freschet, G. T., Fyllas, N. M., Gallagher, R. V., Green, W. A., Gutierrez, A. G., Hickler, T., Higgins, S. I., Hodgson, J. G., Jalili, A., Jansen, S., Joly, C. A., Kerkhoff, A. J., Kirkup, D., Kitajima, K., Kleyer, M., Klotz, S., Knops, J. M. H., Kramer, K., Kühn, I., Kurokawa, H., Laughlin, D., Lee, T. D., Leishman, M., Lens, F., Lenz, T., Lewis, S. L., Lloyd, J., Llusià, J., Louault, F., Ma, S., Mahecha, M. D., Manning, P., Massad, T., Medlyn, B. E., Messier, J., Moles, A. T., Müller, S. C., Nadrowski, K., Naeem, S., Niinemets, Ü., Nöllert, S., Nüske, A., Ogaya, R., Oleksyn, J., Onipchenko, V. G., Onoda, Y., Ordoñez, J., Overbeck, G., Ozinga, W. A., Patiño, S., Paula, S., Pausas, J. G., Peñuelas, J., Phillips, O. L., Pillar, V., Poorter, H., Poorter, L., Poschlod, P., Prinzing, A., Proulx, R., Rammig, A., Reinsch, S., Reu, B., Sack, L., Salgado-Negret, B., Sardans, J., Shiodera, S., Shipley, B., Siefert, A., Sosinski, E., Soussana, J. F., Swaine, E., Swenson, N., Thompson, K., Thornton, P., Waldram, M., Weiher, E., White, M., White, S., Wright, S. J., Yguel, B., Zaehle, S., Zanne, A. E., and Wirth, C.: Try - a global database of plant traits, Global Change Biol., 17, 2905-2935, doi:10.1111/j.13652486.2011.02451.x, 2011.

Keiblinger, K. M., Hall, E. K., Wanek, W., Szukics, U., Hämmerle, I., Ellersdorfer, G., Böck, S., Strauss, J., Sterflinger, K., Richter, A., and Zechmeister-Boltenstern, S.: The effect of resource quantity and resource stoichiometry on microbial carbon-use-efficiency, FEMS Microbiol. Ecol., 73, 430-440, doi:10.1111/j.1574-6941.2010.00912.x, 2010.

Kirschbaum, M. U. F.: Soil respiration under prolonged soil warming: Are rate reductions caused by acclimation or substrate loss?, Global Change Biol., 10, 1870-1877, doi:10.1111/j.13652486.2004.00852.x, 2004.

Klappenbach, J. A., Dunbar, J. M., and Schmidt, T. M.: Rrna operon copy number reflects ecological strategies of bacteria, Appl. Environ. Microbiol., 66, 1328-1333, doi:10.1128/aem.66.4.13281333.2000, 2000.

Kleber, M., Nico, P. S., Plante, A., Filley, T., Kramer, M., Swanston, C., and Sollins, P.: Old and stable soil organic matter is not necessarily chemically recalcitrant: Implications for modeling concepts and temperature sensitivity, Global Change Biol., 17, 1097-1107, doi:10.1111/j.1365-2486.2010.02278.x, 2011.

Knapp, A. K. and Smith, M. D.: Variation among biomes in temporal dynamics of aboveground primary production, Science, 291, 481-484, 2001.

Koven, C. D., Riley, W. J., Subin, Z. M., Tang, J. Y., Torn, M. S., Collins, W. D., Bonan, G. B., Lawrence, D. M., and Swenson, S. C.: The effect of vertically resolved soil biogeochemistry and alternate soil $\mathrm{C}$ and $\mathrm{N}$ models on C dynamics of CLM4, Biogeosciences, 10, 7109-7131, doi:10.5194/bg-10-7109-2013, 2013. 
Kramer, M. G., Sanderman, J., Chadwick, O. A., Chorover, J., and Vitousek, P. M.: Long-term carbon storage through retention of dissolved aromatic acids by reactive particles in soil, Global Change Biol., 18, 2594-2605, doi:10.1111/j.13652486.2012.02681.x, 2012.

Kuzyakov, Y:: Priming effects: Interactions between living and dead organic matter, Soil Biol. Biochem., 42, 1363-1371, doi:10.1016/j.soilbio.2010.04.003, 2010.

Lajtha, K., Bowden, R. D., and Nadelhoffer, K.: Litter and root manipulations provide insights into soil organic matter dynamics and stability, Soil Sci. Soc. Am. J., doi:10.2136/sssaj2013.08.0370nafsc, 2014.

Lawrence, C. R., Neff, J. C., and Schimel, J. P.: Does adding microbial mechanisms of decomposition improve soil organic matter models? A comparison of four models using data from a pulsed rewetting experiment, Soil Biol. Biochem., 41, 19231934, doi:10.1016/j.soilbio.2009.06.016, 2009.

Lawrence, D., Oleson, K. W., Flanner, M. G., Thorton, P. E., Swenson, S. C., Lawrence, P. J., Zeng, X., Yang, Z.-L., Levis, S., Skaguchi, K., Bonan, G. B., and Slater, A. G.: Parameterization improvements and functional and structural advances in version 4 of the community land model, J. Adv. Model. Earth Syst., 3, 27 pp., doi:10.1029/2011ms000045, 2011.

Lee, Z. M. and Schmidt, T. M.: Bacterial growth efficiency varies in soils under different land management practices, Soil Biol. Biochem., 69, 282-290, 2014.

Leff, J. W., Wieder, W. R., Taylor, P. G., Townsend, A. R., Nemergut, D. R., Grandy, A. S., and Cleveland, C. C.: Experimental litterfall manipulation drives large and rapid changes in soil carbon cycling in a wet tropical forest, Global Change Biol., 18, 2969-2979, doi:10.1111/j.1365-2486.2012.02749.x, 2012.

Li, J., Wang, G., Allison, S., Mayes, M., and Luo, Y.: Soil carbon sensitivity to temperature and carbon use efficiency compared across microbial-ecosystem models of varying complexity, Biogeochemistry, 1-18, doi:10.1007/s10533-013-9948-8, 2014.

Liang, C., Cheng, G., Wixon, D., and Balser, T.: An absorbing markov chain approach to understanding the microbial role in soil carbon stabilization, Biogeochemistry, 106, 303-309, doi:10.1007/s10533-010-9525-3, 2011.

Lipson, D., Monson, R., Schmidt, S., and Weintraub, M.: The trade-off between growth rate and yield in microbial communities and the consequences for under-snow soil respiration in a high elevation coniferous forest, Biogeochemistry, 95, 23-35, doi:10.1007/s10533-008-9252-1, 2009.

Liu, L. L. and Greaver, T. L.: A global perspective on belowground carbon dynamics under nitrogen enrichment, Ecol. Lett., 13, 819-828, doi:10.1111/j.1461-0248.2010.01482.x, 2010.

Loreau, M.: Microbial diversity, producer-decomposer interactions and ecosystem processes: A theoretical model, P. Roy. Soc. Lond. B., 268, 303-309, doi:10.1098/rspb.2000.1366, 2001.

Luo, Y., Wan, S., Hui, D., and Wallace, L. L.: Acclimatization of soil respiration to warming in a tall grass prairie, Nature, 413, 622-625, 2001.

Manzoni, S., Schimel, J. P., and Porporato, A.: Responses of soil microbial communities to water stress: Results from a metaanalysis, Ecology, 93, 930-938, doi:10.1890/11-0026.1, 2011.

Manzoni, S., Taylor, P., Richter, A., Porporato, A., and Ågren, G. I.: Environmental and stoichiometric controls on micro- bial carbon-use efficiency in soils, New Phytol., 196, 79-91, doi:10.1111/j.1469-8137.2012.04225.x, 2012.

Melillo, J. M., Aber, J. D., and Muratore, J. F.: Nitrogen and lignin control of hardwood leaf litter decomposition dynamics, Ecology, 63, 621-626, 1982.

Melillo, J. M., Steudler, P. A., Aber, J. D., Newkirk, K., Lux, H., Bowles, F. P., Catricala, C., Magill, A., Ahrens, T., and Morrisseau, S.: Soil warming and carbon-cycle feedbacks to the climate system, Science, 298, 2173-2176, 2002.

Melillo, J. M., Butler, S., Johnson, J., Mohan, J., Steudler, P., Lux, H., Burrows, E., Bowles, F., Smith, R., Scott, L., Vario, C., Hill, T., Burton, A., Zhou, Y.-M., and Tang, J.: Soil warming, carbonnitrogen interactions, and forest carbon budgets, P. Natl. Acad. Sci., 108, 9508-9512, doi:10.1073/pnas.1018189108, 2011.

Metherell, A. K., Harding, L. A., Cole, C. V., and Parton, W. J.: Century soil organic matter model environment. Technical documentation agroecosystem version 4.0. Great plains system research unit technical report no. 4.Usda-ars, Fort Collins, CO, USA, 1993.

Miki, T., Ushio, M., Fukui, S., and Kondoh, M.: Functional diversity of microbial decomposers facilitates plant coexistence in a plantmicrobe-soil feedback model, P. Natl. Acad. Sci., 107, 1425114256, doi:10.1073/pnas.0914281107, 2010.

Mikutta, R., Kleber, M., Torn, M., and Jahn, R.: Stabilization of soil organic matter: Association with minerals or chemical recalcitrance?, Biogeochemistry, 77, 25-56, doi:10.1007/s10533005-0712-6, 2006.

Miltner, A., Bombach, P., Schmidt-Brücken, B., and Kästner, M.: Som genesis: Microbial biomass as a significant source, Biogeochemistry, 111, 41-55, doi:10.1007/s10533-011-9658-z, 2012.

Molenaar, D., van Berlo, R., de Ridder, D., and Teusink, B.: Shifts in growth strategies reflect tradeoffs in cellular economics, Mol. Syst. Biol., 5, doi:10.1038/msb.2009.82, 2009.

Moorhead, D. L. and Sinsabaugh, R. L.: A theoretical model of litter decay and microbial interaction, Ecol. Monogr., 76, 151-174, doi:10.1890/0012-9615(2006)076[0151:atmold]2.0.co;2, 2006.

Moorhead, D. L., Lashermes, G. 1., and Sinsabaugh, R. L.: A theoretical model of $\mathrm{c}$ - and n-acquiring exoenzyme activities, which balances microbial demands during decomposition, Soil. Biol. Biochem., 53, 133-141, 2012.

Nadelhoffer, K. J., Boone, R. D., Bowden, R. D., Canary, J. D., Kaye, J. P., Micks, P., Ricca, A., Aitkenhead, J. A., Lajtha, K., and McDowell, W. H.: The dirt experiment: Litter and root influences on forest soil organic matter stocks and function, in: Forests in time: The environmental consequences of 1000 years of change in new england, edited by: D. Foster, and Aber, J., Yale University Press, New Haven, 300-315, 2004.

Nemergut, D. R., Cleveland, C. C., Wieder, W. R., Washenberger, C. L., and Townsend, A. R.: Plot-scale manipulations of organic matter inputs to soils correlate with shifts in microbial community composition in a lowland tropical rain forest, Soil Biol. Biochem., 42, 2153-2160, doi:10.1016/j.soilbio.2010.08.011, 2010.

Oechel, W. C., Vourlitis, G. L., Hastings, S. J., Zulueta, R. C., Hinzman, L., and Kane, D.: Acclimation of ecosystem $\mathrm{CO}_{2}$ exchange in the alaskan arctic in response to decadal climate warming, Nature, 406, 978-981, 2000.

Parton, W., Silver, W. L., Burke, I. C., Grassens, L., Harmon, M. E., Currie, W. S., King, J. Y., Adair, E. C., Brandt, L. A., Hart, S. C., 
and Fasth, B.: Global-scale similarities in nitrogen release patterns during long-term decomposition, Science, 315, 361-364, 2007.

Parton, W. J., Schimel, D. S., Cole, C. V., and Ojima, D. S.: Analysis of factors controlling soil organic-matter levels in great-plains grasslands, Soil Sci. Soc. Am. J., 51, 1173-1179, doi:10.2136/sssaj1987.03615995005100050015x, 1987.

Parton, W. J., Schimel, D. S., Cole, C. V., and Ojima, D. S.: A general model for soil organic matter dynamics: Sensitivity to litter chemistry, texture and management, in: Quantitative modeling of soil forming processes edited by: Bryant, R. B. and Arnold, R. W., Soil Science Society of America, Minneapolis, Minnesota, USA, 147-167, 1994.

Pfeiffer, T., Schuster, S., and Bonhoeffer, S.: Cooperation and competition in the evolution of atp-producing pathways, Science, 292, 504-507, doi:10.1126/science.1058079, 2001.

Phillips, R. P., Finzi, A. C., and Bernhardt, E. S.: Enhanced root exudation induces microbial feedbacks to $\mathrm{n}$ cycling in a pine forest under long-term $\mathrm{CO}_{2}$ fumigation, Ecol. Lett., 14, 187-194, doi:10.1111/j.1461-0248.2010.01570.x, 2011.

Pianka, E. R.: On r- and k-selection, The American Naturalist, 104, 592-597, doi:10.2307/2459020, 1970.

Portillo, M. C., Leff, J. W., Lauber, C. L., and Fierer, N.: Cell size distributions of soil bacterial and archaeal taxa, Appl. Environ. Microbiol., 79, 7610-7617, doi:10.1128/aem.02710-13, 2013.

R Development Core Team: R: A language and environment for statistical computing, R Foundation for Statistical Computing, Vienna, Austria, 2011.

Ramirez, K. S., Craine, J. M., and Fierer, N.: Consistent effects of nitrogen amendments on soil microbial communities and processes across biomes, Global Change Biol., 18, 1918-1927, doi:10.1111/j.1365-2486.2012.02639.x, 2012.

Resat, H., Bailey, V., McCue, L., and Konopka, A.: Modeling microbial dynamics in heterogeneous environments: Growth on soil carbon sources, Microb. Ecol., 63, 883-897, doi:10.1007/s00248-011-9965-x, 2012.

Rousk, J. and Bååth, E.: Fungal and bacterial growth in soil with plant materials of different $\mathrm{c} / \mathrm{n}$ ratios, FEMS Microbiol Ecol, 62, 258-267, doi:10.1111/j.1574-6941.2007.00398.x, 2007.

Rousk, J. and Bååth, E.: Growth of saprotrophic fungi and bacteria in soil, FEMS Microbiol Ecol, 78, 17-30, doi:10.1111/j.15746941.2011.01106.x, 2011.

Russell, J. B. and Cook, G. M.: Energetics of bacterial growth: Balance of anabolic and catabolic reactions, Microbiol. Rev., 59, 4862, 1995.

Schimel, D. S., Braswell, B. H., Holland, E. A., McKeown, R., Ojima, D. S., Painter, T. H., Parton, W. J., and Townsend, A. R.: Climatic, edaphic, and biotic controls over storage and turnover of carbon in soils, Global Biogeochem. Cy., 8, 279-293, doi:10.1029/94GB00993, 1994.

Schimel, J. and Schaeffer, S. M.: Microbial control over carbon cycling in soil, Front. Microbiol., 3, doi:10.3389/fmicb.2012.00348, 2012.

Schimel, J. P. and Weintraub, M. N.: The implications of exoenzyme activity on microbial carbon and nitrogen limitation in soil: A theoretical model, Soil Biol. Biochem., 35, 549-563, 2003.

Schmidt, M. W. I., Torn, M. S., Abiven, S., Dittmar, T., Guggenberger, G., Janssens, I. A., Kleber, M., Kogel-Knabner, I., Lehmann, J., Manning, D. A. C., Nannipieri, P., Rasse, D.
P., Weiner, S., and Trumbore, S. E.: Persistence of soil organic matter as an ecosystem property, Nature, 478, 49-56, doi:10.1038/nature10386, 2011.

Schnitzer, M. and Montreal, C. M.: Quo vadis soil organic matter research? A biological link to the chemistry of humification, in: Advances in Agronomy, edited by: Sparks, D. L., Academic Press, 143-217, 2011.

Serna-Chavez, H. M., Fierer, N., Van Bodegom, P. M.: Global drivers and patterns of microbial abundance in soil, Global. Ecol. Biogeogr., 22, 1162-1172, 2013.

Sierra, C. A., Trumbore, S. E., Davidson, E. A., Frey, S. D., Savage, K. E., and Hopkins, F. M.: Predicting decadal trends and transient responses of radiocarbon storage and fluxes in a temperate forest soil, Biogeosciences, 9, 3013-3028, doi:10.5194/bg-9-30132012, 2012.

Simpson, A. J., Simpson, M. J., Smith, E., and Kelleher, B. P.: Microbially derived inputs to soil organic matter: Are current estimates too low?, Environ. Sci. Technol., 41, 8070-8076, doi:10.1021/es071217x, 2007.

Sinsabaugh, R. L., Manzoni, S., Moorhead, D. L., and Richter, A.: Carbon use efficiency of microbial communities: Stoichiometry, methodology and modelling, Ecol. Lett., 16, 930-939, doi:10.1111/ele.12113, 2013.

Six, J., Conant, R. T., Paul, E. A., and Paustian, K.: Stabilization mechanisms of soil organic matter: Implications for c-saturation of soils, Plant Soil, 241, 155-176, doi:10.1023/a:1016125726789, 2002.

Six, J., Frey, S. D., Thiet, R. K., and Batten, K. M.: Bacterial and fungal contributions to carbon sequestration in agroecosystems, Soil Sci. Soc. Am. J., 70, 555-569, doi:10.2136/sssaj2004.0347, 2006.

Soetaert, K.: rootSolve: Nonlinear Root Finding, Equilibrium and Steady-State Analysis of Ordinary Differential Equations, R package version 1.4, 2009.

Sollins, P., Homann, P., and Caldwell, B. A.: Stabilization and destabilization of soil organic matter: mechanisms and controls, Geoderma, 74, 65-105, 1996.

Steinweg, J. M., Plante, A. F., Conant, R. T., Paul, E. A., and Tanaka, D. L.: Patterns of substrate utilization during long-term incubations at different temperatures, Soil Biol. Biochem., 40, 2722-2728, 2008

Stone, M. M., Weiss, M. S., Goodale, C. L., Adams, M. B., Fernandez, I. J., German, D. P., and Allison, S. D.: Temperature sensitivity of soil enzyme kinetics under n-fertilization in two temperate forests, Global Change Biol., 18, 1173-1184, doi:10.1111/j.1365-2486.2011.02545.x, 2012.

Strickland, M. S. and Rousk, J.: Considering fungal:Bacterial dominance in soils - methods, controls, and ecosystem implications, Soil Biol. Biochem., 42, 1385-1395, 2010.

Sulzman, E. W., Brant, J. B., Bowden, R. D., and Lajtha, K.: Contribution of aboveground litter, belowground litter, and rhizosphere respiration to total soil $\mathrm{CO}_{2}$ efflux in an old growth coniferous forest, Biogeochemistry, 73, 231-256, doi:10.1007/s10533-0047314-6, 2005.

Thiet, R. K., Frey, S. D., and Six, J.: Do growth yield efficiencies differ between soil microbial communities differing in fungal:Bacterial ratios? Reality check and methodological issues, Soil Biol. Biochem., 38, 837-844, 2006. 
Todd-Brown, K., Hopkins, F., Kivlin, S., Talbot, J., and Allison, S.: A framework for representing microbial decomposition in coupled climate models, Biogeochemistry, 109, 19-33, doi:10.1007/s10533-011-9635-6, 2012.

Todd-Brown, K. E. O., Randerson, J. T., Post, W. M., Hoffman, F. M., Tarnocai, C., Schuur, E. A. G., and Allison, S. D.: Causes of variation in soil carbon simulations from CMIP5 Earth system models and comparison with observations, Biogeosciences, 10, 1717-1736, doi:10.5194/bg-10-1717-2013, 2013.

Todd-Brown, K. E. O., Randerson, J. T., Hopkins, F., Arora, V., Hajima, T., Jones, C., Shevliakova, E., Tjiputra, J., Volodin, E., Wu, T., Zhang, Q., and Allison, S. D.: Changes in soil organic carbon storage predicted by earth system models during the 21 st century, Biogeosciences, 11, 2341-2356, doi:10.5194/bg-11-2341-2014, 2014

Treseder, K., Balser, T., Bradford, M., Brodie, E., Dubinsky, E., Eviner, V., Hofmockel, K., Lennon, J., Levine, U., MacGregor, B., Pett-Ridge, J., and Waldrop, M.: Integrating Microb. Ecol. into ecosystem models: Challenges and priorities, Biogeochemistry, 109, 7-18, doi:10.1007/s10533-011-9636-5, 2012.

Tucker, C. L., Bell, J., Pendall, E., and Ogle, K.: Does declining carbon-use efficiency explain thermal acclimation of soil respiration with warming?, Global Change Biol., 19, 252-263, doi:10.1111/gcb.12036, 2013.

Verberk, W. C. E. P., van Noordwijk, C. G. E., and Hildrew, A. G.: Delivering on a promise: Integrating species traits to transform descriptive community ecology into a predictive science, Freshwater Science, 32, 531-547, doi:10.1899/12-092.1, 2013.

von Lützow, M., Kögel-Knabner, I., Ludwig, B., Matzner, E., Flessa, H., Ekschmitt, K., Guggenberger, G., Marschner, B., and Kalbitz, K.: Stabilization mechanisms of organic matter in four temperate soils: Development and application of a conceptual model, J. Plant Nutr. Soil Sci., 171, 111-124, doi:10.1002/jpln.200700047, 2008.

Waldrop, M. P. and Firestone, M. K.: Microbial community utilization of recalcitrant and simple carbon compounds: Impact of oakwoodland plant communities, Oecologia, 138, 275-284, 2004.

Wallenstein, M., and Hall, E.: A trait-based framework for predicting when and where microbial adaptation to climate change will affect ecosystem functioning, Biogeochemistry, 109, 35-47, doi:10.1007/s10533-011-9641-8, 2012.
Wallenstein, M. D., Haddix, M. L., Ayres, E., Steltzer, H., Magrini-Bair, K. A., and Paul, E. A.: Litter chemistry changes more rapidly when decomposed at home but converges during decomposition-transformation, Soil Biol. Biochem., 57, 311319, 2013.

Wang, G., Post, W. M., and Mayes, M. A.: Development of microbial-enzyme-mediated decomposition model parameters through steady-state and dynamic analyses, Ecol. Appl., 23, 255272, doi:10.1890/12-0681.1, 2013.

Wang, Y. P., Chen, B. C., Wieder, W. R., Leite, M., Medlyn, B. E., Rasmussen, M., Smith, M. J., Agusto, F. B., Hoffman, F., and Luo, Y. Q.: Oscillatory behavior of two nonlinear microbial models of soil carbon decomposition, Biogeosciences, 11, 1817-1831, 10, http://www.biogeosciences.net/11/1817/10/.5194/bg-11-18172014, 2014.

Waring, B. G., Averill, C., Hawkes, C. V., and Holyoak, M.: Differences in fungal and bacterial physiology alter soil carbon and nitrogen cycling: Insights from meta-analysis and theoretical models, Ecol. Lett., 16, 887-894, doi:10.1111/ele.12125, 2013.

Wickings, K., Grandy, A. S., Reed, S. C., and Cleveland, C. C.: The origin of litter chemical complexity during decomposition, Ecol Lett., 15, 1180-1188, doi:10.1111/j.1461-0248.2012.01837.x, 2012.

Wieder, W. R., Bonan, G. B., and Allison, S. D.: Global soil carbon projections are improved by modelling microbial processes, Nat. Clim. Change, 3, 909-912, doi:10.1038/nclimate1951, 2013.

Wieder, W. R., Boehnert, J., and Bonan, G. B.: Evaluating soil biogeochemistry parameterizations in earth system models with observations, Global Biogeochem. Cy., 28, 211-222, doi:10.1002/2013gb004665, 2014.

Xia, J., Luo, Y., Wang, Y.-P., and Hararuk, O.: Traceable components of terrestrial carbon storage capacity in biogeochemical models, Global Change Biol., 19, 2104-2116, doi:10.1111/gcb.12172, 2013.

Xia, J. Y., Luo, Y. Q., Wang, Y. P., Weng, E. S., and Hararuk, O.: A semi-analytical solution to accelerate spin-up of a coupled carbon and nitrogen land model to steady state, Geosci. Model Dev., 5, 1259-1271, doi:10.5194/gmd-5-1259-2012, 2012.

Yang, X., Wittig, V., Jain, A. K., and Post, W.: Integration of nitrogen cycle dynamics into the integrated science assessment model for the study of terrestrial ecosystem responses to global change, Global Biogeochem. Cy., 23, GB4029, doi:10.1029/2009gb003474, 2009. 